\title{
On Unstable Ground: Issues Involved in Greening Space in the Rocinha Favela of Rio De Janeiro
}

\author{
Lea Rekow $^{1,2}$ \\ ${ }^{1}$ Arts, Education \& Law Group, Griffith University, Brisbane, Australia \\ 2 Green My Favela, 59 Franklin St, suite 303, New York, NY 20013, USA; E-Mail: learekow@gmail.com; \\ Tel.: +1 16462572587
}

Submitted: 5 August 2015 | In revised form: 26 March 2016 | Accepted: 1 April 2016 |

Published: 31 May 2016

\begin{abstract}
This paper is based on fieldwork undertaken in conjunction with Green My Favela, a land use restoration project that works with informal and vulnerable income sector residents to reclaim chronically degraded public areas by creating gardens inside the urban favelas of Rio de Janeiro, Brazil. The paper reveals how government intervention policies employed in the lead up to the 2016 Olympics are destabilizing the fragile social fabric of the city's largest favela, Rocinha, through military occupation and urbanization activities that threaten an already low and unstable human security threshold.
\end{abstract}

Keywords: Environmental restoration; favelas; pacification; public security; Rio de Janeiro; urbanization

\section{Introduction}

Brazil is a country with one of the highest economic disparities in the world, where half of the people survive on only ten percent of the income, and more than a quarter live below the federal poverty line. Rio de Janeiro is the second largest city in Brazil-home to approximately fourteen million people of whom approximately $27 \%$ live in dense informal or irregular settlements (favelas) in areas that suffer from state neglect, resource scarcity, and fluctuating levels of violence.

The Rocinha favela is a steep, heavily populated favela located in the South Zone of Rio de Janeiro. It consists of a cluster of more than twenty neighborhoods, made up of dozens of non-cohesive communities [1], and a myriad of fragmented subgroups and sublocations [2]. Rocinha's geopolitical complexity, its economic importance, and its built density offers a rich and multilayered template for exploring how government intervention [3] plays out on the ground to impact on community-centered environmental restoration (ER) and preservation efforts.
The series of case reports described below are based on fieldwork undertaken while attempting to establish a series of micro-scale gardens in Rocinha between 2011 and 2014. The work was carried out in conjunction with Green My Favela (GMF), an ER project that works with favela residents to remediate chronically degraded space and make gardens inside Rio's favelas. The projects provide a working platform from which to explore how the interventionist actions of the state of Rio de Janeiro theoretically hold the capacity to support small socio-environmental efforts within Rocinha, but instead are further unraveling the already fragile social fabric of a favela in distress.

The research focuses on how urbanization and police pacification go hand in hand to affect or interface with ER efforts located within various neighborhoods inside Rocinha. It also describes how drug trafficking and other intra-community conflicts, relationships, and expectations impact on the micro-gardening projects discussed, and evaluates if it is feasible to cultivate productive, green public space inside Rocinha under these conditions. It explicates 
how activities and behaviors around remediating degraded space are impacted by a myriad of government policies, armed conflicts, State [4] abandonment, and social exclusion which interweave to define the complexity of working in Brazil's largest urban favela. These issues compound to make Rocinha an extremely volatile and difficult place in which to try to establish safe and productive public space.

Recognizing how community-centered ER efforts are impacted by Rio's pacification-which connects at the nexus of public security, urbanization, and the 'war on drugs'accordingly requires identifying the interplay of both internal and external social inequities and power relations. How these policies are both aimed at gaining territorial control over favelas in order to further the interests of the ruling class is critical to understanding whose voices Rio's policies serve, and whose voices are ignored in the process. This state of affairs has been thoroughly critiqued by a diverse range of scholars [5].

Studies which focus on the structural realities of socioenvironmental policy include scholars such as Raquel Rolnick, who has been influential in revealing how social inequities in the judicial system penalize the poor. In addition, Gomes and Barbosa's research focuses on urban sustainability as mechanisms of control and resistance [6], and Lucas Cavalcante's writing examines the wider discourse surrounding urban sustainability and policy implementation by focusing on specific impacts and limitations of interventions in some of Rio's smaller favelas [7]. While there is also a sizeable body of evidence available about the interconnectedness of environmental vulnerabilities and resource inequities, political promises to establish frameworks to tackle these problems remain largely unfulfilled.

Advancing urban and socio-environmental policy is defined as a key outcome of Rio's Master Plan for Sustainable Urban Development, as laid out in Complementary Law No. $111 / 2011$ [8]. Specifically, under this law, the municipality has formulated and implemented policy based on a range of principles, including: environmental conservation and social equity; appreciation, protection and sustainable use of the environment; universal access to infrastructure and urban services; promoting broad social participation; universal access to land; cooperation between various government bodies, the private sector and other societal sectors in the urbanization process in compliance with social interest; preservation of environmental areas; integrated planning and urban management aimed at ensuring the sustainable development of the City; coordinating the actions of all levels of government to promote initiatives of common interest concerning the environment, environmental sanitation, urban infrastructure, and public services; the urbanization of favelas, irregular and illegal settlements, with the implementation of infrastructure, sanitation, public facilities, recreational areas and reforestation, aimed at their integration into formal areas of the City, except in the situations of risk and environmental protection; the adoption of urban solutions that increase the safety and avoid fragmentation and compartmentalisation of the urban fabric; the recovery, rehabilitation and maintenance of public open spaces built on degraded or underutilized areas; promoting the appropriate use of empty or underused or idle land, prioritizing its use as open spaces for community use, parks, green areas and recreational areas; and promoting democratic management of the City.

As this paper aims to demonstrate, to date the implementation of this municipal policy framework has largely failed Rocinha. In addition, there has been little analysis as to how these policies impact on community-centered efforts that aim to rehabilitate degraded land. Little attention has been paid to how these policies support or impede specific attempts by irregular sector groups to insert themselves into this ER framework, or to analyze the results of policies that are delivered in either limited or inconsistent ways. Therefore, there is still a need to investigate (i) the reality of socio-environmental interactions in favelas (ii) the micro-impact of policy failure within favela communities in regard to ER, and (iii) any potential socio-environmental policy shifts that could benefit Rocinha and other large favelas or favela complexes like it.

\section{Objectives and Scope}

Enacting any form of environmental remediation inside of almost any of Rio's urban favelas requires overcoming a range of socio-political, socio-economic, public security, and geographical complexities. This presents a formidable challenge. In the context of Rocinha, where risk of conflict is strongly perceived [9], fear and mistrust is embodied in a range of physical and symbolic structural assemblages [10]. In addition, many forms of social interventions reinforce the concept of colonial oppression and produce a spiral of meanings and volatile behaviors that react to the interests at play [11]. Accordingly, by examining what actually happens in the field, it is possible to see how environmental restoration efforts interface with the structural inequalities of a socially segregated city [12] where both macro and micro conflicts are catalyzed or accelerated by events and approaches that generate mistrust and fear.

As such, this paper seeks to bring to light the interplay between specific social, environmental, and security challenges encountered in Rocinha during the first three years of pacification, using the ER projects that GMF has participated in as a field guide. The study aims to explore if ER projects can be sustained; if they produce benefits for residents; how State intervention impacts on these projects; how this relates to issues associated with territorial control and access to land; and what macro- and sub-level conflict arises between actors as a result. Moreover, it attempts to reveal the complex social interface of Rocinha under pacification, and to identify incongruities in values, interests, knowledge and power relations between State and non-State actors.

The research may be useful or of interest to those working inside non-international internal armed conflicts, or within the areas of public security policy, fragile cities, en- 
vironmental remediation, poverty studies, informality, urban planning, or urban agriculture.

\section{Methodology}

The bulk of the qualitative information collected for this paper was obtained in the course of co-producing the seven $\mathrm{ER} /$ gardening projects discussed below. The research is primarily based on material gathered from the many unstructured conversations and interactions had by the author and other members of the GMF team while working in Rocinha with residents to make gardens between November 2011 and March 2015. It links to the pillars of action research in that it involves processes of collective problem solving and engages with community efforts that are inextricably tied to collective action [13-16]. It also interfaces with what Bogdan and Biklen interpret as the collection of evidence designed for the purpose of exposing unjust practices and environmental dangers, and for assessing or recommending actions for change [17].

Crime statistics provide a source of secondary data; however, the difficulty of obtaining reliable figures due to underreporting made the fieldwork an important measure for qualifying official public data [18]. By working with different actors and various social interfaces over a prolonged period of time, these field actions were instrumental in yielding a nuanced understanding of the evolving macro- and micro-level political structures that operate in Rocinha, and how they differ from neighborhood to neighborhood.

The projects were located in various parts of Rocinha, were of different sizes and types, and involved a variety of actors [19]. The diversity of the projects provided a variety of fields and social interfaces in which to work-in various neighborhoods with a wide range of poverty levels; a disparate array of working partners; assorted plots of degraded land; different grades of infrastructure and resource access; various levels of capital investment; fluctuating levels of human security; conflicting forms of armed governance; and significant social and natural geographic variances. The work aligned with the stated social goals of government intervention-in particular in regard to producing the sustainable social occupation of space [20].

\section{Organizational Framework}

GMF was used as the organizational framework through which to approach this study because it offers a unique structure through which to interface with many different social planes. GMF is a locally based international organization founded by the author in 2010 . It is a collaborative, action-based ER organization and research support platform that works with individual favela residents, residents' associations, NGOs, schools, and multiple tiers of government, to improve existing urban space by remediating degraded lands and making gardens. GMF works with concepts of practical hands-on knowledge exchange to open up opportunities for people, materials, ideas, and organisa- tional assemblages to reshape space that has long been prone to abuse and neglect. These spatial co-productions aim to explore how the informal sector can drive and participate in the re-generation of safe social space and improve the daily lives of favela residents.

GMF also collaborates with a range of external partners including private philanthropists, academic institutions, grassroots organizations, research networks, artists, social innovators, and individual researcher/practitioners working in an array of diverse fields (including sustainability, anthropology, landscape architecture, environmental ethics, the arts and humanities, policy studies, global studies, environmental studies, and urban planning). In addition, GMF explores, advises on, and attempts to implement solutions that address issues relating to garbage and recycling, food and water security, public health and educational programming inside favelas.

\section{Background and Context}

The history of Rio de Janeiro's favelas began in the late 1880s with the abolition of slavery as Brazil transitioned from the Portuguese empire to a Republic in its own right. Throughout the course of the next century, the city's favelas grew and experienced significant changes. Initially, these communities were made up of a mixture of squatter settlements, farming communities, and legally parceled residential areas. In time, rural-to-urban migrants and itinerant laborers also began to occupy favelas. As various formal residential and industrial areas were abandoned, these too became informal occupations. Decades of removals of these low-income populations have also shifted urban density from one favela to another.

As favelas became more numerous and increasingly populated, residents began to organize, forming local associations and labor unions. These organizations served as forums for deliberating on community matters. Since the government failed to extend public services or legal protections to the favelas, community members, led by their local associations, formed their own systems of transportation, sanitation and utilities services, commerce, and governance.

Amidst the political turmoil of the 1980s, the City of Rio de Janeiro became an important export node for cocaine transiting from the Andes to the United States and Europe. It also developed as an internal consumer market for the drug. As a consequence of the evolving drug trade, levels of violence skyrocketed. By the mid-1990s, Brazil was considered one of the world's most violent nations not in a state of war, and Rio's favelas began to be compared to internal armed conflicts.

The favelas, with their unmapped geographic complexity and built density, and without the protection of the State, became prime territory from which the drug trafficking gangs operated. As gangs took over the control of more and more favelas, the young men living inside their boundaries came under intense pressure to join the trafficking culture. They also became the principal victims of homicide, not only as 
a result of gang-related incidents, but because of the enormous number of extra-judicial killings that Rio's police have become so infamous for. Rio's multiple military and civil police forces, notorious for using extreme force with almost total impunity, were responsible for 8,466 deaths in the state of Rio de Janeiro between 2004 and 2015. Statistics show that, on average, four out of every five victims that die at the hands of police are poor, black and aged between fifteen and 29 years of age [21].

In 2006, in order to satisfy the International Olympic Committee, Rio began to devise a series of interventionist policies designed to overcome this violent image and offer a more alluring and marketable picture of the city. Several state and municipal policies and programs have since emerged, including the Unidade de Polícia Pacificadora (UPP), a state military campaign that was implemented to secure territorial control over strategically located favelas; and Morar Carioca (the Informal Settlements Integration Program), an urbanization program designed as a cornerstone of Rio's Olympic City legacy, as laid out in the city's Master Plan for Sustainable Urban Development [22-25].

As a result, almost ten thousand UPP military troops have been deployed to favelas, and $R \$ 8$ billion has been pledged to 'upgrade' and 'integrate' favelas into the formal city. The favela upgrades include the installation of sanitation, water drainage, street lighting, roads, public green spaces and recreational areas, transportation networks, home stabilization, and social service centers [26]. The UPP coordinates with the Municipal Housing Secretariat (SMH)-the department that oversees the city's urbanization projects-to facilitate the regularization of utilities and services, to shut down informality, and to enforce housing removals.

More than delivering anything else however, Rio's urbanization projects have provided an abundance of lucrative state-backed corporate profiteering opportunities to a select few. Public contracts have been exclusively awarded to a handful of private consortium and construction companies that, under current policies, are able to skirt normative democratic processes under the banner of the Olympics legacy [20]. This accelerated neoliberal policy or the "festivalization of politics" as Häußermann and Siebel describe it [27] - is designed as a landscape of exceptionalities in which favela territory is appropriated without due process $[22,28]$ in order to advance political and private gain.

Rather than integrating favelas, creating critical infrastructure, promoting community-led social projects, addressing unemployment, mitigating the spread of disease, providing public security and so on, these programs-at tremendous public cost-have done little more than protect the bourgeoisie and generate enormous profit for the largescale entrepreneurs that are the major private contributors to the electoral campaigns of Rio's governor and mayor [20]. This slew of top-down interventions disguised as social investments are decided by politicians and corporate entrepreneurs who insist "they know what is good for the city" [22], yet for all intents and purposes they appear to be designed to be good for themselves.

\section{The Layout of Rocinha}

The Rocinha favela is Rio's most thickly populated informal settlement, with more than twenty neighborhoods tightly packed into less than a square kilometer of land (Figure 1). Census reports calculate the population at 69,000 [29] but unofficial estimates reach as high as 200,000 . Whatever the actual figure, Rocinha is the largest of Brazil's favelas, where most residents subsist in closely packed housing units stacked up to eleven stories high.

This self-contained city is a compact concrete labyrinth comprised of dark, narrow tunnels (Figure 2) and steep winding alleys littered with mounds of garbage and snaking grey streams of open sewerage that spill down the steep mountainside to the ocean below. One congested main road twists through it from top to bottom. Motorbikes ferry residents up and down through a jumbled network of housing and commerce bubbling with lively and vivacious social exchanges taking place in the markets, stores, bars, restaurants, schools, and churches.

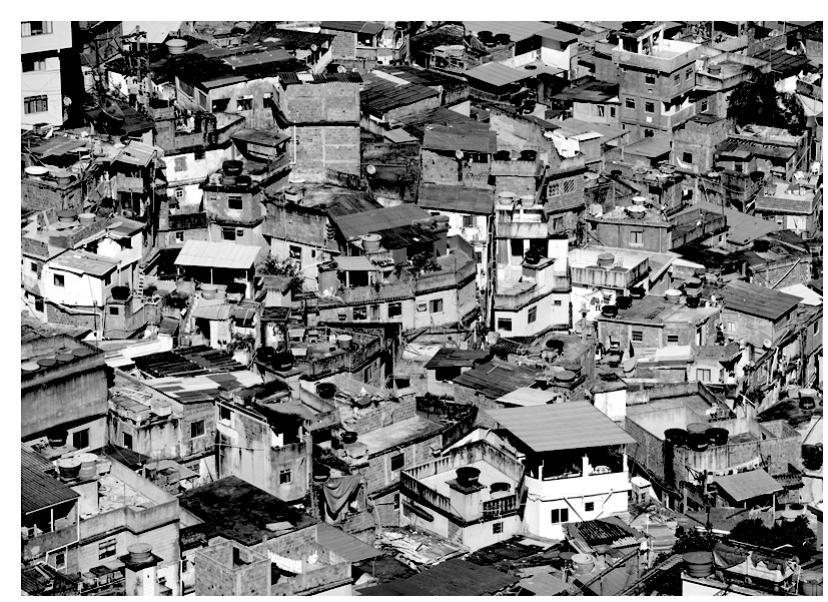

Figure 1. Detail of Rocinha favela housing.

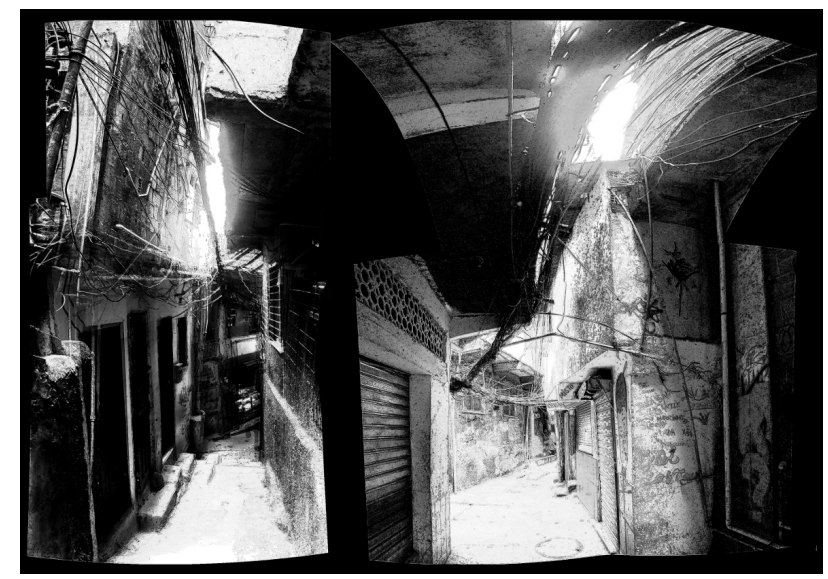

Figure 2. Rocinha becos (alleyways) in the Valão neighborhood. 
The favela is geographically squeezed in between two of the Rio's most affluent neighborhoods, São Conrado and Gávea. It falls almost at the bottom of the city's Human Development Index (HDI). While the HDI of Gávea surpasses that of Norway (the country with the highest-ranking HDI in the world) a hundred yards away in Rocinha, average life expectancy is cut by thirteen years [30].

Though living conditions in specific favelas under pacification vary depending on context and institutional arrangement, the people face common struggles that can be largely characterized by the use of force wielded by the power of the State-wherein vertical public policies deliberately silence residents and leave little room for effective community participation-through the naturalization of structural inequality that is a deliberate extension of historical segregation [31].

\section{Control and Security in the Favela}

The majority of Rio's favelas are governed by "micro-level warlords" [32] that control the three major gangs that monopolize Rio's lucrative drug trafficking economy. Rocinha plays a major part of this trafficking landscape. It has been suggested that as much as $R \$ 100$ million is generated from the drug trade annually in this favela alone [33].

For decades, Rocinha was governed by a succession of drug trafficking bosses and gangs, each of which resulted in a series of violent events that dictated the course of trafficking in the community. In 2004, Antonio Bonfim Lopes, known simply as Nem, took control of the favela to govern under the banner of the Amigos dos Amigos (ADA) gang. Under Nem, Rocinha functioned in relative peace and unity. Nem was considered somewhat of a benevolent leader who was rumored to have entered the drug trade as a way to pay for his baby daughter's critical health care needs (she suffered from a rare blood disease). Nem won the respect of many residents by establishing a series of community services such as food banks.

At the beginning of Rocinha's pacification in November 2011, however, thousands of state anti-terrorist military units moved into Rocinha on masse - in foot battalions, with dogs, and on horseback, supported with armored tanks and helicopters. Nem was arrested and many of his senior dealers were killed. Consequently, the ADA heirarchy crumbled and traffickers splintered into sub-groups, which has sparked an internal conflict for control of territory. Though 700 UPP officers are now stationed in Rocinha, operating out of several military posts which control the most accessible parts of the favela, the ADA is still a major drug trafficking force to contend with, despite their internal turmoil.

Currently the ADA leadership of Rocinha is unified under Rogério Avelino da Silva, the drug boss known as Rogério 157. Since pacification, the ADA has reestablished a significant presence in at least six neighborhoods, including the Valão, Cachopa, Macega, and Porto Vermelho. However, many 'soldiers' and 'managers' are restless under Rogério's leadership. This has triggered several factional takeover attempts that manifest in unpredictable and in- tense exchanges of gunfire. Therefore, Rocinha residents not only endure battles between the UPP and the ADA, and between the ADA and the CVs (who vie for control of the upper reaches of the favela), but also between competing factions within the ADA. Adding to the instability, the UPP have also been accused of corruption, torture, drug trafficking, rape, extra-judicial killings, and disappearances.

The UPP is expected to remain an implemented policy at least until the realization of the Olympic Games. However, as the state sinks deeper and deeper into a negative economic growth crisis, together with the loss of the UPP's principal funders [34], pacification looks less and less viable over the long-term. It is generally assumed that the policy will be, in large part, dismantled after the Games, leaving a power vacuum that is likely to lead to extensive bloodshed as drug trafficking factions compete to reestablish territorial control.

\section{Understanding Urbanization}

Along with the military intervention of pacification, Rocinha was granted federal investment funding of $R \$ 231.2$ million to be directed toward urbanization interventions that were contracted to private enterprises to provide infrastructure, housing and community facilities, and to recover degraded areas [35]. The funding was assigned to Brazil's Growth Acceleration Program (PAC) and dispensed in part by the state and the municipality.

Urbanization projects often begin with the removal of residents from their homes. Scholars Luke Faulhaber and Lena Azevedo estimate that more than 65,000 people, mostly from low-income areas and informal settlements, have been evicted in the lead up to the Olympics, many forcibly and through violent processes [36]. Yet the city continues to defend its housing policy and denies compulsory removal without guarantee of a new home or compensation by negotiated resettlement [37]. Even so, the Municipal Court of Auditors has found the $\mathrm{SMH}$ legally responsible for failing to pay compensation to families in Rocinha [38]. And though Rio's Mayor, Eduardo Paes, directs critics to a government web portal that details the transparency of the policy as it effects each neighborhood, the data sets consist of nothing more than empty fields. Therefore, any access to technical reports, the number of expropriations, the cost of resources, the number of removed families, and where they have been relocated to, remains obscured [39].

City Hall justifies many removals through claims of safeguarding residents that are geologically at-risk of landslide. The threats are calculated by the municipal 'Geo-Rio' program, which surveyed and identified six high geo-risk areas in Rocinha [40] and subsequentaly designated the removal of 543 families and the demolition of their homes $[41,42]$. According to a 2014 human rights violation report, evictions happen without community discussion, and without residents having access to information that justifies the need for their removal [43]. In addition, the demolitions leave abandoned, semi-bulldozed ruins and piles of rubble in their wake which become areas that present an array of public health and safety risks as well as leaving families homeless (Figure 3). 


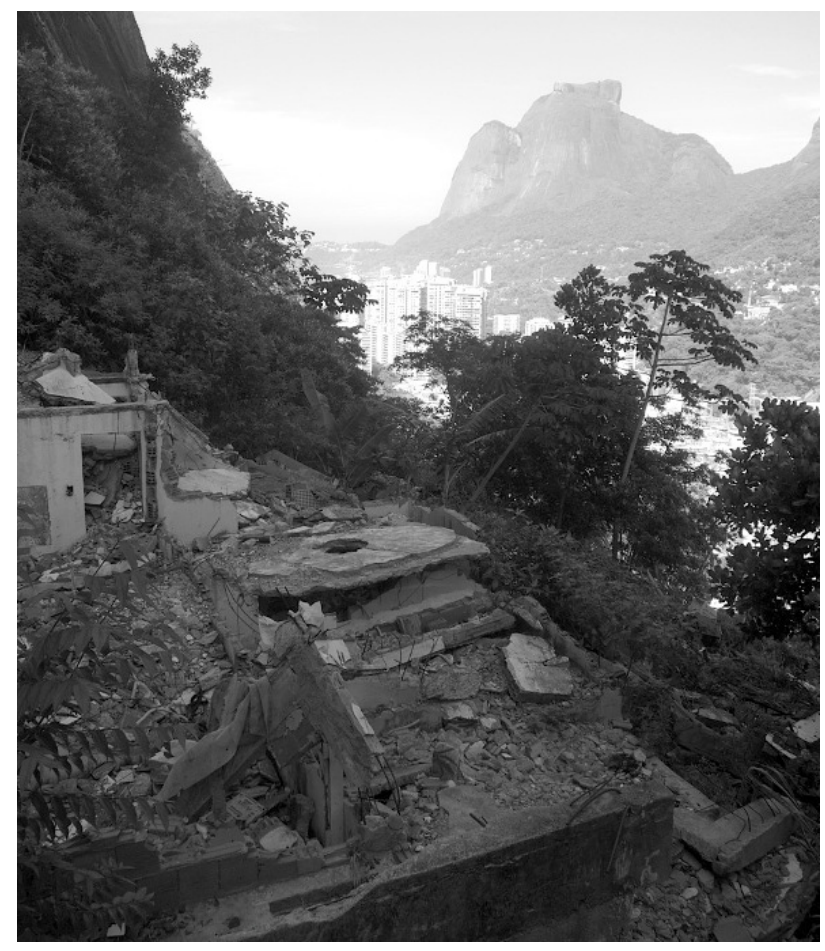

Figure 3. Demolished housing, Macega neighborhood of Rocinha.

Removals are also premised on protecting forested conservation areas. In 2008, 182 favelas encroached on, or were found to be located within 400 meters of protected environmental areas (APAs). Between 2003-2008 Rocinha expanded into its neighboring APA by $4.34 \%$. In 2009 , according to technical estimates by City Hall, there were at least 850 homes in the Vila Verde and Macega neighborhoods of Rocinha that needed to be removed because they were located in São Conrado's Area of Ecological Interest. In Macega, according to the municipality, at least 50 houses had been built in the APA in a number of months. However Leonardo Rodrigues Lima, spokesperson for the Pro-Improvement of Rocinha Union, denied the claim, stating that "Of course in Rocinha there are people in risk areas surviving in miserable conditions. But there are no shacks in the environmental area". Instead, he claims, it is the affluent formal residents of São Conrado and Gavea whose mansions impede on the forest [44]. Though the problem of eating into the Atlantic rainforest is important to address, City Hall's solution-to build a series of 'eco-walls' around the favela to contain it-has been heavily criticized, with comparisons being drawn between Rio and Israel's Segregation Wall. The construction of the walls also involves removals of families, which in turn has led to more unsustainable development in other parts of the Atlantic Rainforest as people rebuild where they can.

The spatial restructuring of Rocinha is also subject to other crises. PAC invested $R \$ 219.3$ million in infrastructure projects in Rocinha, yet due to overspending, work ground to a halt in 2011 [44], leaving half-finished projects abandoned. Construction sites and semi-completed buildings have become squats for people in need of housing [45], while the lack of basic sanitation and education continue to remain critical problems. Rocinha's community leaders have appealed to federal prosecutors to investigate the State Secretary for Works (responsible for implementing PAC projects) for spending on low priority projects which were either not completed or were hurriedly opened to coincide with elections. Some residents were initmidated by PAC to leave their homes without being compensated fairly, and as a result they have had to accept a much lower standard of living. As the PAC projects failed to advance, their abandoned homes, some of which had belonged to the same family for generations, were taken over by drug dealers and addicts [46].

Many question the nature of Rocinha's upgrade interventions and their ability to fulfill residents' needs without creating unnecessary negative impact. José Martins de Oliveira, founder of Rocinha sem Fronteiras (Rocinha without Borders), reflects the sentiment of Rocinha residents by making the point that, more than anything, upgrades need to focus on improving sanitation conditions in order to reduce diseases such as tuberculosis, dengue, zika, and hepatitis, all of which present substantial health problems in Rocinha $[47,48]$.

\section{Greening the Favela in a Climate of Risk}

The opportunity to work in various locations throughout Rocinha has provided a unique position from which to examine issues relating to both the social and military interventions brought about by pacification. If the attempts at creating urban gardens discussed below can be broadly understood as fragile negotiations between space and conflict, then they can help expose the fundamental spatial-political incongruities in Rocinha at this time. These projects reveal the duplicitous policies and concealed patterns that working in these circumstances present. They also point to how contributing to reshaping public space could potentially serve as a way to forge, modify and expand community experience and affiliations.

For the purposes of this report, the processes involved in creating community gardens in Rocinha are activities that can be generally characterized as attempts to produce various forms of productive green space. The benefits of the provision of parks [49], the therapeutic activities related to gardening [50], and the gains presented by urban agriculture in underserved communities [51] are all well documented. The production of desirable and publically accessible green space holds the potential to strengthen mental health, provide therapeutic support, build capacity, encourage cooperation, exchange knowledge, cultivate inclusivity, and reduce poverty, yet inside informal urban settlements such as Rocinha, residents are often deprived of such opportunities.

The cultivation of productive green space, as a viable urban poverty intervention strategy has been thoroughly discussed in much literature from the 1960s on. Studies 
have been carried out, particularly in relation to the socioeconomic benefits of urban agriculture in various categories, including home production systems and open space locations [52]. However, scholarly texts that specifically discuss urban agriculture in the inner-city favelas of Rio are relatively few [53-57]. In addition, though studies have been conducted in relation to conflict resolution regarding rural land tenure [58], there are few studies that pay attention to the interface between gardening and its relationship to territorial conflict inside fragile informal urban contexts $[59,60]$.

Concerns about undernutrition, cancer, heart disease, diabetes, asthma, obesity, depression, and emotional stress in urban populations are growing. Diminished decisionmaking capacity is also beginning to appear in studies as a consequence of poverty, with far-reaching effects [61-63]. In informal settlements, these problems are enormous and demand multi-level responses [64].

With an estimated one billion more people expected to be living in informal poverty conditions within the next twenty years, a primary concern is food security. Urban farming offers informal communities huge benefits. In Rio, where food prices can jump as much as $17 \%$ in a month, reducing this vulnerability to the market is extraordinarily valuable for low-income earners living in a state of economic instability [56].

The relief brought through therapeutic and educational resources that gardens provide has been shown to be beneficial to physical and mental health. Parks and gardens are increasingly valued for their restorative qualities. Significant benefits have been proven to be associated with having access to nature, including its ability to relieve stress and cultivate a sense of stewardship for the land. Psychologically there is satisfaction that comes from the joy of growing and sharing food. These activities can contribute to relationship building that, in turn, can lead to community cohesion and enhanced levels of belonging. This is connected to building social capital $[65,66]$, an important aspect of wellbeing that encourages cooperation among individuals and groups, and an essential component of a functioning society [67].

The physical benefits just from being able to view gardens are measurable in reduced blood pressure, diminished pain levels, fewer physical complaints, and accelerated healing [67]. Community gardens have also become recognized as an important means with which to recover from or cope with conflict and war [68]. So what does it mean to green even ten square meters of Brazil's most densely populated favela? Can such projects offer opportunities to learn about environmental education, gain a better understanding of nutrition, enhance food security, reduce pollution, mitigate erosion, or improve social space-and can such space be sustained in a climate of conflict and risk?

\section{GMF Field Actions Report}

The field actions described below are collaborative projects conducted by GMF over a three-year period. They generally follow the same production format, to:

1. identify an available site;
2. establish relationships with favela residents, local stakeholders, and external partners (step 1. and 2. may be reversed or happen simultaneously);

3. obtain relevant permissions with various state and non-state actors (including gang authorization) to move forward;

4. coordinate human, physical and financial resources;

5. engage in collaborative actions to create food, medicinal, or therapeutic gardens;

6. transition management to residents;

7. provide ongoing support if requested.

Once access to a site has been gained, the work begins by clearing trash (Figure 4). The first and most fundamental step of creating a community garden in the favela is the removal of tons of trash and housing debris. This is often the most challenging work, to remove massive amounts of garbage and rubble manually by carrying it up or down long, winding, slippery and narrow, tunnel-like becos (alleyways; Figure 2). To trek through this $80+$ year old, steep, densely packed favela with heavy loads of everything from the remains of collapsed or bulldozed housing to old appliances and bags of heavy waste, to and from areas reachable only on foot, requires great effort and considerable physical labor, and can at times pose a threat to personal security.

Once a site has been cleared and cleaned up, infrastructure is built-terraces, retaining walls, fences, garden beds-and water tanks installed. Soil, seeds and tools are provided, irrigation systems are set up, compost and worm bins are assembled. Advice on organic agriculture, composting, and children's workshops and planting days are held. Once a garden is fully established and the community feels ready to fully take over governance and maintenance of a space, GMF steps away from the project and continues to provide adjunct support and resources upon request. The projects rely to a lesser extent on capital investment in hard infrastructure, and more on social infrastructure (human and social capital) as the critical assets needed to produce and maintain gardens.

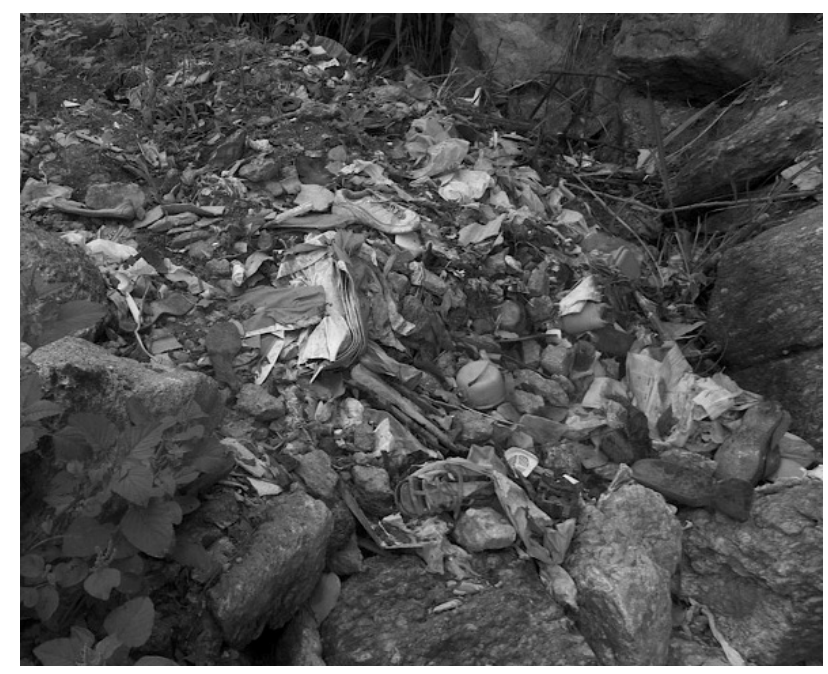

Figure 4. Trash littering the ground in Macega. 


\subsection{Valão}

Groundbreaking on the first garden in Rocinha began in November 2011 at the same time as the UPP occupation of the favela began to unfold. GMF's pilot project was a garden called Rocinha Mais Verde. The garden is located in the Valão neighborhood, one of the poorest communities in the favela, located at the bottom of Rocinha where the bulk of the open sewers flow. The Valão is a crowded, narrow and winding warren of cramped concrete residential structures built on top of one another so densely that little sunlight penetrates in many areas. The majority of the favela sewerage channels to this area. The sewers are clogged with litter and overflow during heavy downpours. Animal feces and trash cover the narrow pathways. The more open, accessible areas of the neighborhood are brimming with commerce and markets. Before pacification, this included bocas (street stalls that sell drugs, mostly cocaine), guarded by young teenage soldiers armed with heavy artillery. Since pacification, the bocas have disappeared into the nooks and crannies of the back alleyways, and the police now visibly display the heavy weaponry and regulate mobility through the more accessible parts of the neighborhood.

The Rocinha Mais Verde garden was Rocinha's first community garden. The project developed as a collaboration between GMF and the late Lino dos Santos Filho (Tio Lino), an important community leader who worked in Rocinha for more than 30 years to make art from recycled materials with children, with the aim of deterring them from joining drug gangs [69].

Tio Lino had gained access to a steep, vacant lot of land around $50 \mathrm{~m}^{2}$ that had been used for years as a garbage dump. The land was adjacent to Tio's NGO_Rocinha Mundo da Arte-on a plot belonging to the Alegria das Crianças Creche. A two meter high pile of trash had built up on top of the site and another two meters had been compressed into the soil (Figure 5).

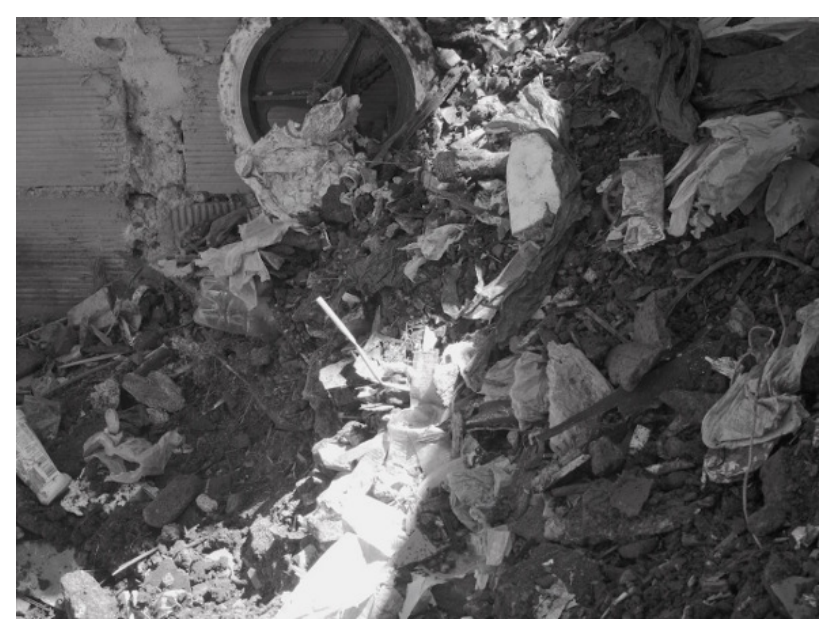

Figure 5. Trash buildup in the soil at the Rocinha Mais Verde space.
With funding from a private philanthropist, the physical help of 14 international volunteers, the children from Tio Lino's NGO, and a resident worker from Rocinha, GMF began transforming the space the week the UPP occupation began. First, the garbage was painstakingly hauled away. Some materials were repurposed, including bricks that were used to build a series of terraces, steps, pathways, and garden beds (Figure 6). The remaining trash was pried, sifted and raked out of the topsoil, which was then tested by Brazil's federal soil research facility, Empresa Brasileira de Pesquisa Agropecuária for nutrient and toxicity values. The soil was enriched with organic fertilizer, earthworms, and mulch. Trash was removed from a contaminated, underground water tank that then was cleaned and sealed. Pipes were laid to a new water supply that linked to city water. A compost pile was created, worm bins set up, and a simple homemade drip irrigation system was devised and installed by a resident using recycled plastic bottles.

Flowers, shrubs, fruit trees, and organic edibles were planted with the children from Tio Lino's art school. These hands-on educational workshops also included painting and drawing vegetables, studying seeds under microscopes and through magnifying glasses, tasting vegetables and taking them home to their families, and making terrariums from discarded plastic bottles planted with herbs.

Establishing security and governance over Rocinha Mais Verde proved to be complex. The project unfolded during the largest political upheaval the favela had ever seen, and the stress on the community was palpable. The garden brought attention from all sectors-police, residents, traffickers, government, and the international community. Progress became heavily influenced by security issues. First, the ADA traffickers had to approve and support the project. Then the head of the social arm of the UPP requested a meeting with GMF, which posed a huge security risk, and so was evaded. It has since been alleged that some of those who liaised with police during the early stages of the UPP occupation have been killed in gang retribution actions [70]. Others have been punished or intimidated by community members for their interactions with police.

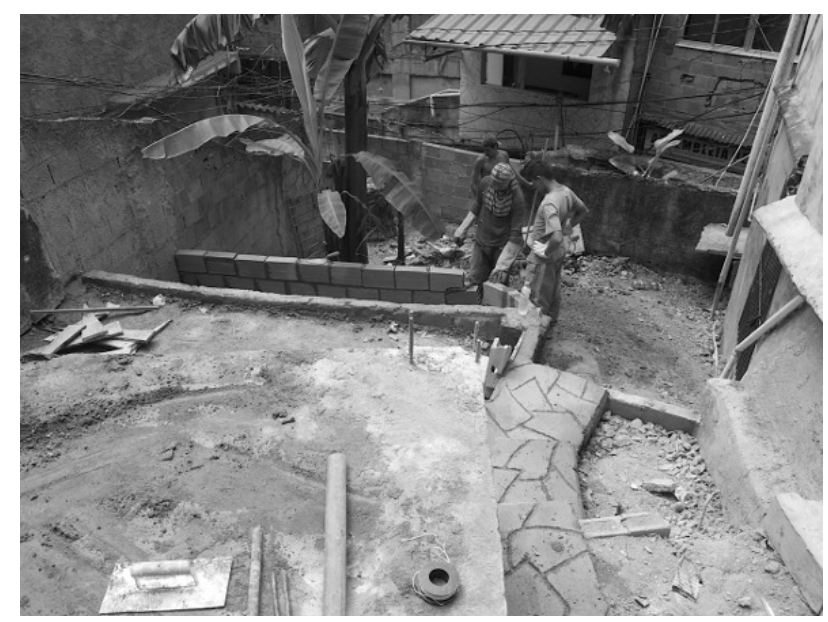

Figure 6. Terracing Rocinha Mais Verde. 
The location of the project in the Valão was a priority for police intervention during the initial phase of pacification. The military takeover of the favela was led by the Batalhão de Operações Policiais Especiais (BOPE) troops, who are infamous for their aggressive military tactics. At the beginning of the military occupation, both gardeners and children were intimidated by BOPE patrols. Security proved not simply an issue for police verses traffickers, but for the community as a whole. The threat amplified the community's conflicting feelings towards the practicality of cultivating public space. Despite their anxiety, however, community stakeholders chose to continue to move forward with the project amidst the chaos and uncertainty.

By June 2012 the daily governance of the space was fully in the hands of the art school, with GMF continuing to provide adjunct support to the project. The local resident who had worked with the project from the beginning was hired to maintain the garden and work with the children. GMF interns from an international environmental studies program from the University of California Santa Cruz, on exchange at PUC University in Rio, augmented the environmental education programming and created a planting schedule. The garden became a space that produced a range of herbs and seasonings, edible vegetables, flowering ornamentals, and fruit. More importantly, it developed as a therapeutic garden, learning space, an art space for children, and a space for local residents to visit (Figure 7). In total, around 200 people began interacting in or visiting the space.

Rocinha Mais Verde was subsequently showcased at the 2012 United Nations Rio+20 Summit on Sustainable Development as an outstanding example of sustainable design.[66] During the summit, GMF began advising Rio's State Department of Social Assistance and Human Rights to strategize on garbage collection, recycling policy, and programming inside Rocinha's public schools. As interest in the project grew, GMF began attending community meetings inside the favela, and identifying other spaces to work in [71].

Over the next two years, the project received much attention and flourished as a recreational and educational space where children participated in gardening-related activities (Figure 8). Within Tio's NGO, however, conflict began arising over issues of control and structure as a new director began redefining the organization. Relations between the NGO and the creche (the landowners of the garden) also began to strain.

$\mathrm{R} \$ 8,000$ was awarded to the Rocinha Mais Verde project by the United Nations Development Programme (UNDP) to continue work in the garden. The money was channelled through Rocinha Mundo da Arte, but rather than generating enthusiasm, the grant set off a series of internal power struggles within the NGO. The competition for control over the newly acquired financial resources interfered with the ability of the NGO to focus on the task at hand, and resulted in the money being absorbed into the organization. This damaged relations between stakeholders. Later, Tio handed over the maintenance of the garden to the creche, which profited from it through a municipal grant they received to upkeep the space. As a consequence, the creche began to perceive outside participation as a potential threat to its funding. When the source of this funding ended, the garden fell into disrepair.

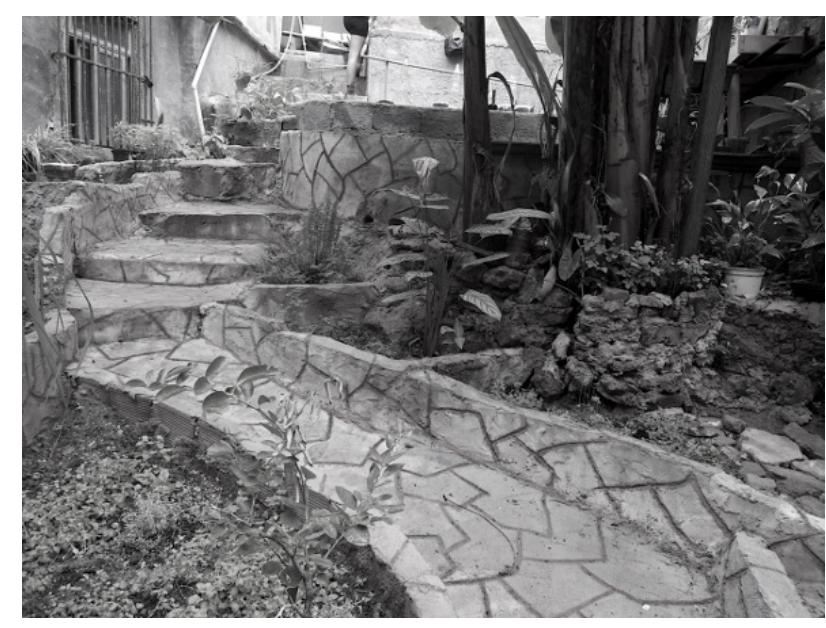

Figure 7. Rocinha Mais Verde.

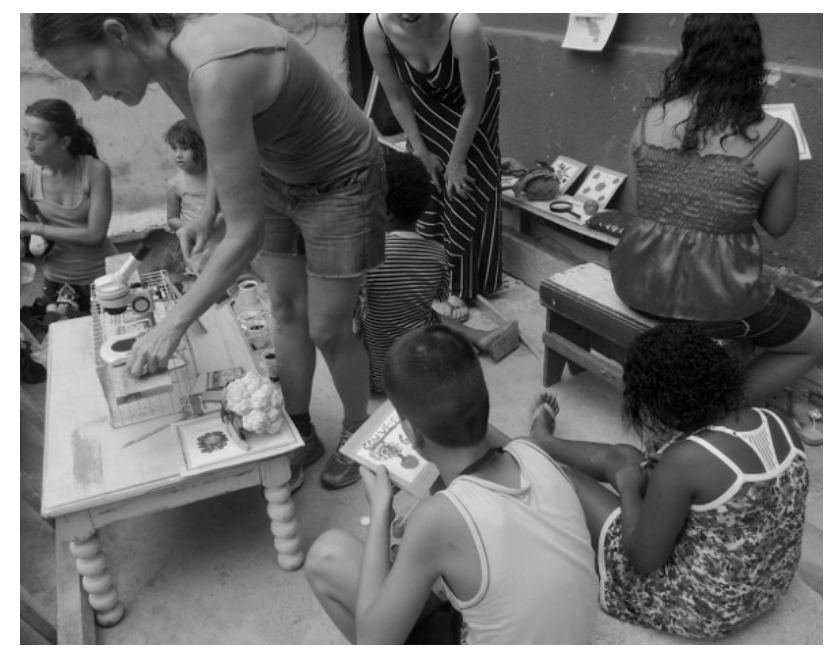

Figure 8. Children's workshop at Rocinha Mais Verde.

In mid 2014, the project suffered a further setback with 63 year-old Tio Lino passing due to health complications relating to his diabetes, a condition that he had battled for years. Though Tio's legacy and organization was passed on to his family, it suffered a devastating loss of leadership and vision. A further two years on, the NGO and the creche continue to struggle for symbolic control over the project, as the garden continues to suffer.

This scenario reflects a level of inter- and intracommunity conflict between individuals that is seen frequently in Rocinha. A lack of individual or group trust, coupled with an inability to resolve internal conflict may, in part, be due to the link between poverty and reduced cognitive function and decision-making ability [72]. The perceived scarcity of external funds may also be partially attributable to this sort of investment being so foreign to stakeholders. Other hardships, including the regular threat of armed conflict and the deeply established culture of drug trafficking, has also had a detrimental effect on individuals in their ability to deescalate conflict, feel comfortable with risk-taking, and apply clear thinking [73].

Studies indicate that the threat and anxiety associated 
with such an increased cognitive load can hinder the processing of information, which in turn can impact on individual task performance [74]. Adding to this, individuals may perceive intra-community conflict between members of a group or groups as a challenge to their own capabilities or competencies [75]. This sort of intra-community conflict has been well documented in the studies of Carnevale and Probst [76]. Jehn and Bendersky [73] have further explored this scenario within group interactions by examining how group conflict narrows attention spans and inhibits integrative problem-solving abilities. Instead, group members are likely to respond to group conflicts by focusing on the turmoil rather than advancing the work. The consequences are that conflict impairs group performance, innovation, and work satisfaction [77].

Another issue Tio Lino's death brings to light in relation to the sustainability of these projects is the health of core individual partipants. This plays a major role in whether or not these projects can remain viable over the long term. There are many inequalities that contribute to the health and healthcare crises suffered by people, especially the elderly, who live in Rio's favelas. Most notably they have considerably lower life expectancy. Men, on average, live 12.8 years less than their counterparts in the formal neighborhoods that surround them. Even more shocking, for both men and women older than age 65 years, healthy life expectancy in favelas is less than half when compared to Rio's wealthiest sector [78]. A variety of environmental issues connected to the open sewer and the built density also raises the public health risk of contracting dengue [79] and tuberculosis [80], both of which are substantially more prevalent in Rocinha than anywhere else in the state. If ill health befalls project custodians or key actors, the health of social projects such as these can also be jeopardised. As Janice Perlman concludes from her work in favelas, "patterns of context, attitudes, behavior, and luck play out in the struggle to overcome the exclusion and dehumanization of poverty" [81].

Due to security constraints, it has not been possible to develop other projects in the Valão. Four years into the pacification, the area remains one of the most volatile neighborhoods in Rocinha. As of the time of this writing, tensions between trafficking factions, the UPP, and the BOPE teams that continue to patrol the area often result in exchanges of gunfire [82]. As a consequence of the collapse in the trafficking hierarchy, opposing factions vie for control of the drug trade in this neighborhood, adding to the incidents of armed conflict. In addition, since 2013, traffickers have established periodic curfews that are publicly announced by ADA foot soldiers who walk through the Valão shouting for residents to go inside in preparation for what has come to be known as 'a shootout at an agreed upon time'. With the bocas continuing to collect approximately $R \$ 30,000$ per month in drug sales, many consider it an economy still worth fighting for [83].

\subsection{Cachopa}

The second project GMF orchestrated in Rocinha was revitalizing a garden in a thin triangle of land located along a well-traveled, steep and winding alleyway connecting Cachopa-a crowded neighborhood perched on a particularly steep hillside - to Rocinha's main road, Estrada da Gávea. Though it receives little sunlight and measures only six meters square, this little plot has a dramatic view of Dois Irmãos mountain and forms the scenery for hundreds of residents' journeys to and from work each day. Water pipes run just below the surface of the soil, which is critically eroded, and one side of the plot is a sheer drop-off. GMF worked with the neighbors of this abandoned lot to remediate the space. Trash was cleared and soil was brought in. Flowers, groundcover, herbs, and shade trees were planted in containers, crates and vertical planters. Vegetable and fruit vines were trained along the fence. A mural was painted on the wall, mirrored tiles were used as an aesthetic device and to increase the amount of sunlight the space received, and a worm bin was installed to process food scraps (Figure 9).

Initially the neighbors were estranged from one another, but the interactions that occurred through the activity of gardening opened up a relationship that involved not only material production but the exchange of ideas and emotions, which evolved into a social practice and created an opening for shared cultural experience. This laid the groundwork for fostering a form of solidarity, in that it created a willingness for neighbors to take the risk of helping each other through taking on an informal form of public responsibility [84]. The importance of this is that it formed the basis for trust, cooperation, and new social ties. The garden requires little maintenance, and though it has suffered some physical setbacks (a paint spill from another neighbor's house and the theft of some edibles), it continues to receive regular upkeep from its neighbors. Due to the heavy foot traffic that moves through the area, the space continues to earn a positive response from the general public. Over time however, the general social stability of the neighborhood has deteriorated.

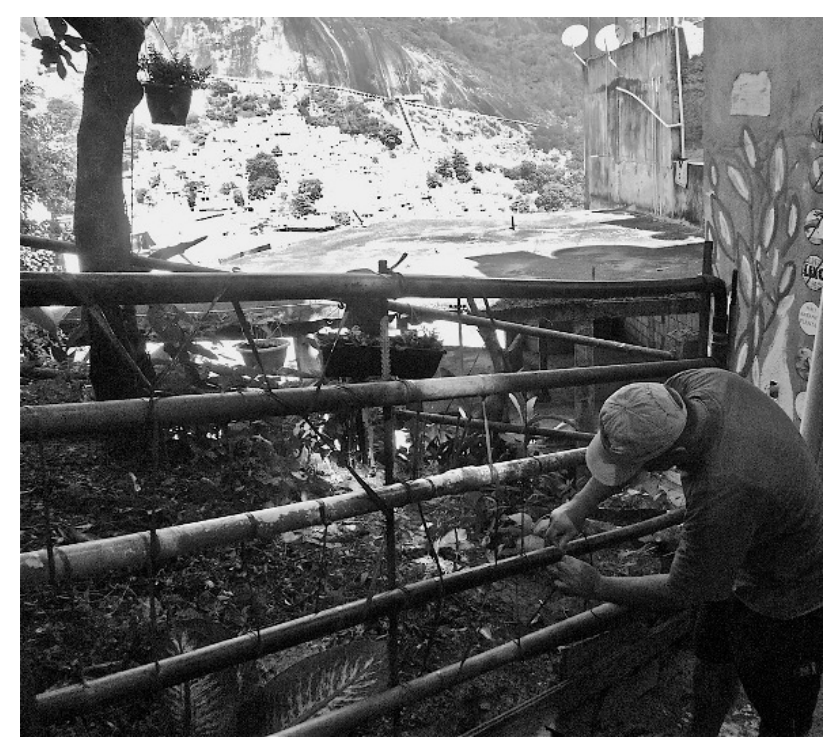

Figure 9. Resident creating a trellis on the fence at the Pedacinho da Terra garden in the Cachopa neighborhood of Rocinha. 
In early 2015, traffickers retook control of some parts of Cachopa [85] and the security situation became critically unstable. In February 2014, 60 traffickers armed with assault rifles attacked Cachopa's UPP post, injuring both the unit's general coordinator and its commander. The conflict spilled over into the Valão. Transformers, cars, surveillence cameras, and power generators were shot out, grenades were thrown, and tires were set on fire on the freeway at the entrance to the favela, causing the closure of Zuzu Angel tunnel which connects the districts of São Conrado and Gavea [86].

In addition, in September 2013 a nine year old girl was found raped and murdered in a vacant lot not more than a hundred meters from the Pacifying Police Unit in Cachopa [87], and in July 2014, a young woman was raped at gunpoint by a trafficker as she was walking home [88]. These actions in particular, demonstrate how the rule of gang law-that strictly forbade any form of sexual assault, theft or domestic violence-is no longer in place. Brutal as it may have been, the 'law of the favela' did function as a way to regulate and control social behavior. This has clearly dissolved under the UPP and the further destabilization of social order has disabled any opportunity to build social capital. The quality and extent of social interactions possible under the current security situation has shaped a daily norm whereby social cohesion cannot prosper.

\subsection{Porto Vermelho}

The Parque Ecológico da Rocinha (Ecological Park of Rocinha) was the focus of a cluster of GMF projects which began in August 2012. The $R \$ 24$ million invested by the State Fund for Environmental Conservation and Urban Development to finance the park was an attempt to provision for the APA at the boundary of Rocinha, and in doing so quell the backlash the State received after building a series of three meter high 'eco-walls' through the neighborhood to physically contain the area [89]. With a stated goal of arresting deforestation through the prevention and removal of housing in areas at risk of landslide, the government proposed building fifteen kilometers of these cement walls around fourteen of the city's favelas.

However, after the walls drew intense international criticism a new plan was needed to resell the concept to the public. In Rocinha, this involved designing the $9,000 \mathrm{~m}^{2}$ ecological park. With impressive culture and leisure facilities [90], the park was to be nestled within in a small wedge of Atlantic rainforest between the Portão Vermelho, Laboriaux, and Cobras e Lagartos neighborhoods of the favela. The eco-walls would function to delineate park boundaries and to protect the Mata Atlântica (Atlantic Forest) APA area. The Atlantic Forest is one of the most diverse biomes in the world, yet it is critically endangered with only seven percent of original forest remaining. In the 25 years preceding the construction of Rio's first eco-wall in 2009, the state had lost 176,714 hectares of this fragile ecosystem [44].

The problems that manifest at the remote boundaries of the favela present many practical, ethical, political, health and security dilemmas. The dense vegetation and remote isolation of the areas at the edges of Rocinha provide seclusion and escape routes for drug traffickers, making them precarious and dangerous. Many believe this was the primary reason behind the construction of the walls in the first place- to fence in the drug trade. State lawmaker Marcelo Freixo claims the government's strategy in building the walls was not to protect the forest but rather "to control poor communities" in order to appease the middle and upper classes. Further, though poverty may be linked to deforestation and habitat loss, it cannot be isolated from political and governance issues. Though there are an estimated 210 irregular constructions in Rocinha's APA, with a 300,000 low-income housing deficit crisis in Rio, Freixo believes that people living in favelas should not be blamed for the problem of deforestation. Additionally, the SOS Mata Atlantica Foundation draws attention to the fact that the forest is not only impacted by the expansion of favelas, but by the luxury condominiums, homes and hotels that continue to encroach on it with almost total impunity [91].

Raquel Rolnick [92] also believes the issue of deforestation is prejudice against the poor and points to judicial decisions to back up her claim. Rolnick cites several cases where judges have ordered the demolition of favela housing, yet have protected mansions that invade forested areas on the argument that the financial investment made in these expensive buildings cannot be ignored. For example, Rolnick claims that in the space of one week in 2013, two judgments were made, one determining the necessity for removal of favela housing for environmental reasons, and the other determining that residents of two luxury condominiums in Gávea-in undisputed violation of the Forest Code - could remain [93].

The social isolation that already existed at this boundary of the favela has been exasperated by the extensive removal of families, first in order to construct the wall, and subsequently to create the eco-park. Though the project initially received community support and employed the majority of its construction workers from Rocinha, 181 families were consequently relocated in order for the massive PACled project to move forward [94]. Lead architect of the park, Café Anderson, rationalizes the removals by emphasising the high levels of built density and poverty in this neighborhood, which creates elevated health and safety risks for the local population [95].

GMF's involvement in the park began by working with elderly residents, who lived by the entrance to the park, to plant a vertical garden on a stretch of retaining wall measuring 45 meters in length and three meters in height [96]. Each of the 1,000+ bricks in the wall were filled with soil and compost and used as planters for a range of ornamentals, medicinal herbs, fruits, seasonings, succulents, and hanging vines. Residents who lived adjacent to the garden protected and maintained the space until it became self-sustaining. Though the garden has suffered small setbacks from time to time, it has managed to regenerate itself and continues to flourish (Figure 10). UPP troops use this wall as a lookout point, and though having armed troops 
patrolling the wall with M16s during the planting process made it a somewhat surreal and uncomfortable process, it did not pose a major disruption to the project.

The next task GMF embarked upon came at the request of Caio, a construction supervisor who owns a midrise mixed use building next to one of the park boundaries. Caio's five storey home rises up to overlook the park on one side and São Conrado's impressive oceanfront skyline on the other. The ground floor functions as a rental garage for six to eight vehicles worth $\mathrm{R} \$ 280$ per parking space, and his newly finished top floor boasts a small self-contained studio apartment which fetches $R \$ 780$ in monthly rental fees. Multi-storey buildings such as Caio's have become more profitable under pacification, catalysing gentrification and stimulating a vertical housing construction boom, despite a 2011 legal decree prohibiting new vertical private construction in the favela [97].

Caio's family live on the residential floors of his building. The master bedroom faces the park and receives little direct sunlight. Its walls are covered in thick black mold, the smell of which hangs heavy in the air and presents the potential threat of tuberculosis. TB is contracted by breathing in bacteria that survive in airborne suspension for several hours in small rooms without fresh air or sunlight. Brazil occupies $17^{\text {th }}$ place within the group of 22 countries that account for $80 \%$ of the world's tuberculosis cases. The state of Rio de Janeiro has the highest number of people infected by TB nationally, and Rocinha has the largest number of tuberculosis cases in the state, with the disease effecting 372 people out of every 100,000 - eleven times higher than the national average (2015) [98]. Moreover, the Cobras e Lagartos neighborhood, where the eco-park is located, has the highest incidents of TB in the favela, and therefore, in Brazil.

In an effort which served to open up the space behind Caio's building, a plan was crafted to establish a fruit and vegetable garden directly opposite the property against the eco-wall (Figure 11). GMF cleared the area and removed a sizeable amount of rubble. The soil was tilled and prepared for planting, but ironically the project stalled when it was discovered that park regulations prohibited the fencing in of the garden. As a consequence, Caio understandably chose not to move forward with the project. To grow an unfenced vegetable garden in an area where there were not enough neighbors to watch over it made the project impractical. Instead the space now grows native shrubs and trees.

At the invitation of the park's lead architect, Café Anderson, GMF then began to develop a large trilateral section of the park. With the same problem of having no residents to directly watch over the space, GMF decided to design the large terraced area as a wild food forest where the public could forage for food-a common practice in favelas. Local residents helped clear the land for GMF to plant a range of fast-growing fruit trees, vegetable vines, and other hardy food types that could survive without maintenance. Groups of children also brought seeds from their favorite fruit trees to plant. Park workers watched over the gardens for a time; however, due to a variety of issues, including restricted ac- cess, a critical budget shortfall, and the failure of the state to fund park maintenance, they were unable to continue and the park began to fall into isolation and disrepair.

Plans for the park started suffering setbacks as early as November 2012. The mismanagement of construction funds resulted in a 30\% cost overrun, and eventually PAC abandoned its work unfinished [99]. In addition by March 2013, the UPP, whose headquarters are located in the park, had begun prohibiting access to a large section of it, including most of its leisure facilities and nature walks.

In July that year, Amarildo de Souza, a 42 year old resident bricklayer, 'disappeared' from UPP headquarters. It was later discovered that de Souza was killed while being interrogated by the UPP. The police allegedly used electric shocks and waterboarding on the victim before suffocating him with a plastic bag. Testimonials by residents claim that de Souza's body was disposed of inside the park. A total of 25 UPP police officers were subsequently arrested and charged with de Souza's torture and the concealment of his corpse. In the months that followed de Souza's disappearance, more than 22 Rocinha residents filed reports of being tortured at the same UPP headquarters in the six months preceding his disappearance [100].

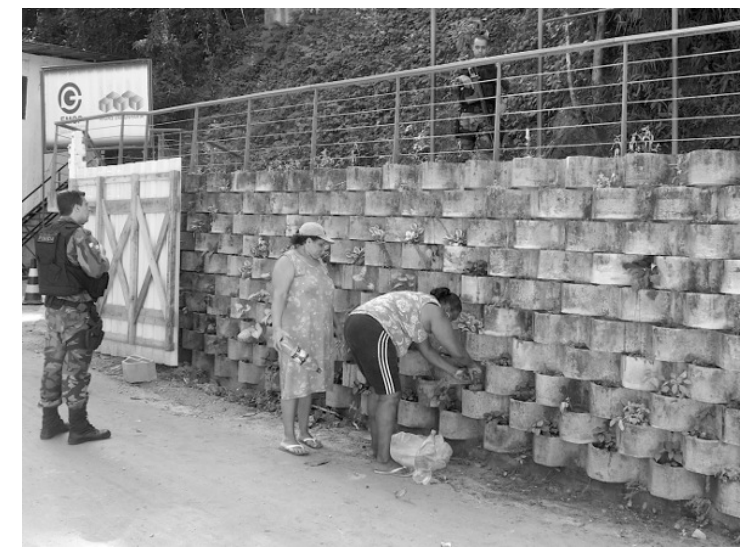

Figure 10. Planting a vertical garden with residents near the entrance to Rocinha's ecopark as UPP officers look on during their patrol.

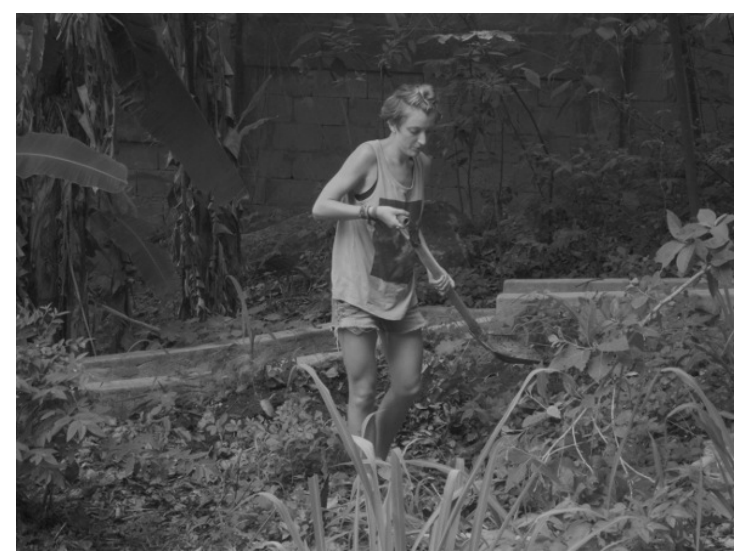

Figure 11. GMF at work in the ecopark, the 'eco/segregation wall' in the background. 
To date, the park remains uncompleted, dangerous, and rarely frequented by residents. A chronically eroded dirt access road makes it difficult and dangerous to transit, a place where pedestrians and motorists alike percieve to be at risk, and where parents are fearful for their children to walk. With a lack of street lighting, and the UPP headquarters where Amarildo was tortured and killed, residents do not feel safe.

Since 2015 , citizens groups have periodically attempted to engage the public in using the space and claiming responsibility for its maintenance. However, with many facilities being abandoned without completion, addressing the park's deficits is challenging. In addition, residents remain terrified to walk the path that leads past the UPP. Instead of this wonderful area providing a space for family entertainment, for playing sports, or for enjoying cultural activities, the park has become an ominous threat, and largely useless to the people of Rocinha. Set in stunning nature, with some of the most beautiful views of the city, PAC's Ecological Park of Rocinha should be one of the jewels of the city. However, with so many shortcomings, the space sits desolate, falling apart, and avoided by residents. If nothing else, the ecological park is emblematic of the disturbing and complex reality of state intervention as it moves aggressively forward in Rocinha.

\subsection{The Laboriaux}

The Laboriaux neighborhood of Rocinha is located above the eco-park and has spectacular views of the city (Figure 12). Approximately 4,000 people live in this historic area, one of the favela's more affluent neighborhoods. The Laboriaux was originally settled in the early 1930s, when land was given away by a local politician who used it to buy votes. A further 80 plots were parceled out by a local real estate company and formally sold. By 1937, however, development had stalled and by the end of the decade formal infrastructure had been abandoned and the neighborhood began taking shape as an informal settlement.

Due to the steepness of the neighborhood, landslides have been a problem in the Laboriaux, but the community remains suspicious of the intentions behind attempts by the city to force their evictions as formal real estate development threatens to advance forcefully in this area. Many residents have already had their homes demolished and been compelled to move. Others, however, have successfully fought relocation and have secured the right to stay in their homes [101].

At the beginning of 2013, GMF was invited to collaborate with the Municipal Secretary of the Environment's Hortas Cariocas program to develop a mid-size food garden in the Laboriaux. The project was funded in part by an urban planner from Columbia University who received a Davis Peace Grant to work with GMF on the space. The right to use the land was approved by the State Department of Human Rights and Social Assistance (SEASDH) - the social arm of the UPP at the time.

Though residents of the immediate area had been removed from their homes, and the surrounding buildings slated for demolition, GMF worked enthusiastically with members of the Laboriaux community to terrace the site, prepare to install water tanks, and ready it for planting. Hortas Cariocas provided a stipend to four local workers, who were employed to teach food gardening to students from a nearby public elementary school, where another smaller garden was also being established as part of the same collaboration. The two projects were designed to support one another.

However, in August the same year, Rio's Municipal Secretary of Housing $(\mathrm{SMH})$ bulldozed the garden without any warning and without consulting stakeholders-community representatives, residents, the Municipal Department for the Environment, SEASDH, or GMF. The garden was demolished in order to provide a place for the city to park heavy machinery while continuing to demolish homes and build walls around the perimeter of the favela (Figure 13).

The event demonstrated a critical lack of communication and coordination between municipal government departments, and between state and local government tiers. It was symbolic of a general disregard toward community achievements, demonstrated a serious lack of government oversight, and resulted in a strong multiplier effect. The incident also pointed to several other principal government functions that failed the people, including failure to know and respond appropriately to citizen efforts, failure to protect community assets, failure to promote responsible land stewardship, and failure to provide mechanisms to hold government accountable for the consequences of their actions.

President of Laboriaux Residents' Association, José Ricardo Duarte Ferreira has many complaints about the lack of appropriate government action regarding its urbanization works. He cites that in 2013, Mayor Paes declared that the Laboriaux' steep mountainside slopes would be fortified, and that families at-risk would be relocated. However, the city only contained the slope and demolished at-risk housing in areas that faced wealthy neighborboods, while the city left other properties at environmental risk as they were. As this demonstrates, the government is in critical need of establishing good practices when it comes to transparency, communication, and legitimacy. Obscuring information, or neglecting to make it accessible internally or to the public, represents a serious obstruction to governance. It also underscores the need for community-validated programs and the capacity to build effective, inclusive support for them.

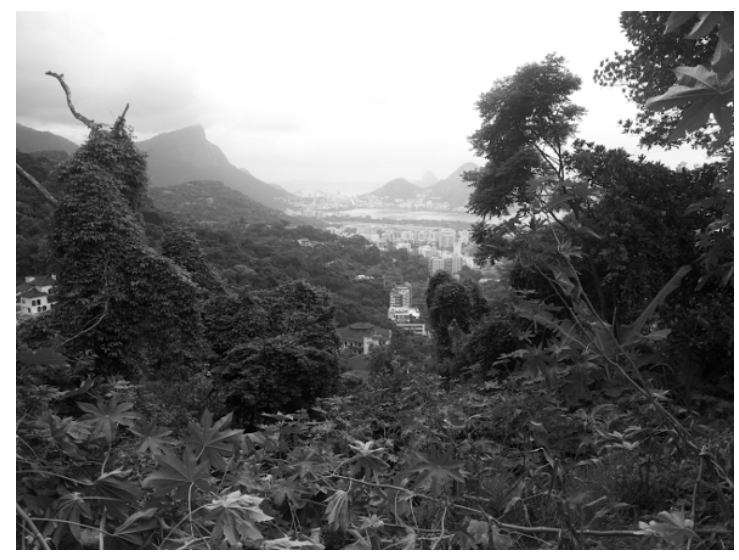

Figure 12. View from the Laboriaux garden. 

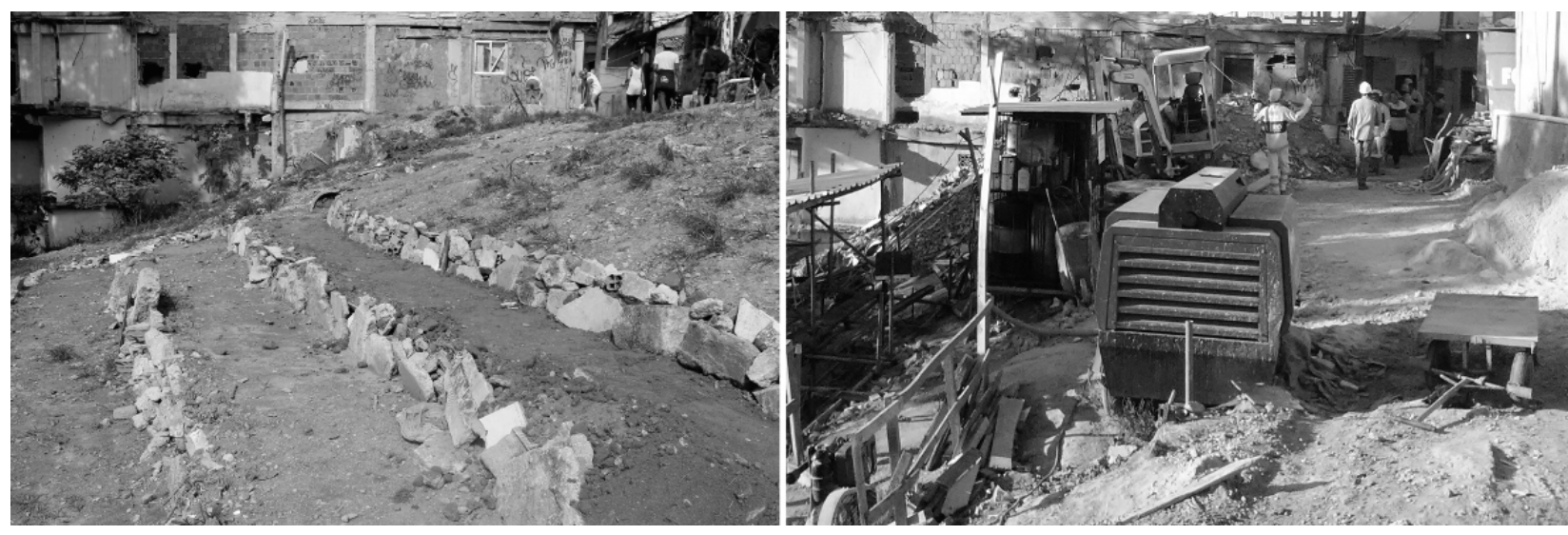

Figure 13. Laboriaux garden terraces, prepared for planting (left) and after the SMH moved onto the site (right).

\subsection{Macega}

Macega is a very poor neighborhood that sits on the upper rim of Rocinha, lodged against the rockface of the Dois Irmãos mountains. Its stunning panoramic views overlook the Atlantic Ocean, the beachfront skyline of São Conrado, and Rocinha's entire thatched favela landscape. Macega is an area of intense spatial and social complexity. The residents of this neighborhood are some of the poorest and most at-risk in Rocinha. The primary source of income for residents comes from burning the plastic coating off wiring scavenged from trash to access the internal copper core. There is an abysmal lack of sanitation-not even the open sewer reaches here. Macega is permanently damp due to its very narrow lanes and alleys that are overshadowed by the mountain and receive little sunlight. The only access the community has to a water supply is through collection from a natural well in the rockface, which runs dry in the summer months and overflows to flood the neighborhood during times of heavy rain. There are no indoor toilets, so residents must openly defecate. Housing ruins, mountains of trash, and mounds of human and animal feces litter the area. Macega's remote location is also known as a stronghold for drug trafficking. People that live here do so because they lack an alternative.

Dozens of homes in this area have been demolished by the municipality under the city's Morar Carioca program, some because of the risk of landslide, others in an attempt to displace traffickers. Despite the destruction of homes, or possibly as a consequence of it, squatters have moved in to reoccupy the area, erecting shanties from the demolished housing debris.

Toward the end of 2012, GMF was invited by SEASDH and the Hortas Cariocas program to work in Macega to coproduce a large food garden in a massive space that terraces down the mountainside from the upper edge of the favela (Figure 14). GMF orchestrated a series of large-scale, on-theground actions to help clear tons of trash from this severely compromised space. The organization donated tools, seeds, labor, and produced cultural interventions to aesthetically improve the area. The garden has an orchard and several large vegetable gardens maintained by a local resident. Neighborhood residents forage for jackfruit and acerola berries here. It is common for children to climb trees to collect food in the favelas, but in Macega foraging constitutes a larger part of their diets. There is a high proportion of children living in this area, many of whom are undernourished.

Though the physical area of Macega has the potential to expand into a sizeable and much needed food security project, the neighborhood is acutely compromised and underserved because of its physical isolation and links to drug trafficking. Accessing the space is difficult. It requires a ten to fifteen minute walk either up a steep incline or across the favela through dangerous and winding becos. This means it is difficult to bring in materials, take trash out, or even get to the space quickly, easily or safely. The municipality eventually withdrew from the project due to these access issues, and SEASDH due to the heightened security risks the neighborhood posed.

GMF continued its physical presence in Macega for a time, but a combination of factors arrested progress. The UPP police put substantial pressure put on gardeners to reveal information about traffickers in the area, which elevated anxiety for the workers involved. In addition, the lead gardener suffered from mental health problems, which included delusional behavior that presented in the form of violence and intimidation toward women [102]. This produced a situation where two female participants were subject to the threat of violence, harassment, and acts of aggression, which created an unhealthy and potentially dangerous work environment and stifled the ability to develop stable working relationships.

In addition, there is an amplified feeling of state abandonment and a historic legacy of violence, murder and displacement in Macega. Drug trafficking murders in the area still occur with some frequency in the vicinity of the garden. Early in June 2013, a murder occurred in close proximity to the garden, and around the same time an unidentified body part was unearthed in the space. Due to the instability of the area, and the reality that the presence of GMF was potentially generating conflict, a decision was made to eventually end involvement in the area. 


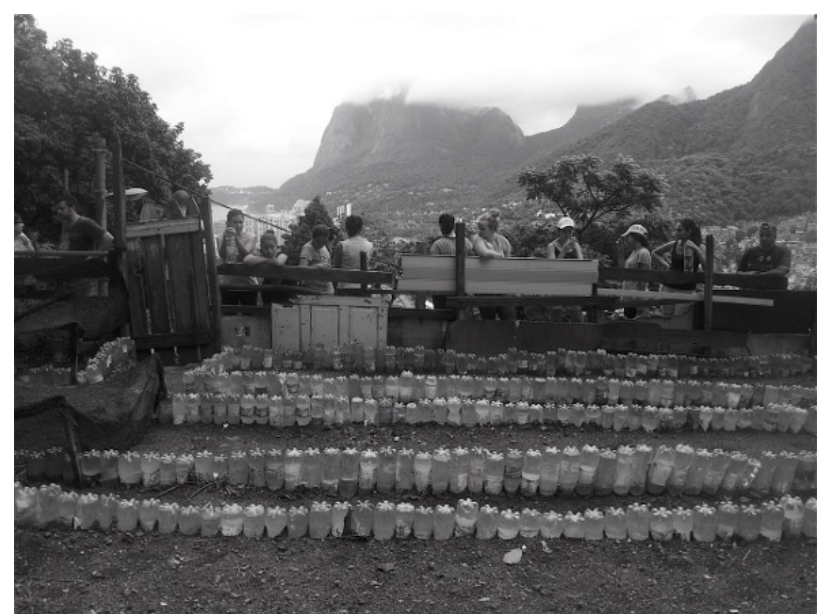

Figure 14. GMF volunteers overlooking the Hortas Cariocas Macega garden after a long workday.

The garden and orchard still provide food for the local community, however Macega remains critically neglected and underserved. The ADA have resumed control of access to the area at one major entry point. This location is now guarded by heavily armed traffickers. Exchanges of gunfire continue, either due to inter-factional fighting or clashes with the UPP. At this point in time, access to the upper part of Macega, where the garden is located, is now restricted by the Department of Civil Defense.

\section{Summary Evaluation: A Landscape of Conflict and Obstacles}

What these attempts at cultivating productive space indicate is that a lack of one resource or service can partly be compensated by another, but if a multiplicity are compromised, diverted, or withdrawn, these projects are prone to collapse. State level contributions (or lack thereof) directed toward improving natural, social, and capital resources, all play a crucial role in stabilizing or destabilizing favelas such as Rocinha. Competition for them also generates a source of intra-community conflict. A volatile public security landscape that not only fails to protect citizens, but actually leads to elevations in levels of violence, also hinders the ability of favela communities such as these to stabilize. Inappropriate and mismanaged State interventions, guided by non-participatory policy and top-down planning create insecurity, especially regarding access and rights to land.

Causes of macro-level conflict center around issues of territorial control. Hegemony over space remains at the heart of politics in Rocinha. The drug war, exploited for political interest, is emblematic of this crisis, as is the State's attempts to seize territory in the lead up to the Olympics. In both cases the central goal remains the same, which is to control access to limited resources.

These projects not only illuminate macro-level obstacles, but also provide a framework for understanding the micro-level social interfaces that are at play, and the impact they have on local efforts to make public space productive.
A lack of shared goals, different financial expectations or dependencies, misappropriation of funds, theft, self-esteem issues, identity and status are central themes of micro-level conflict within projects or groups. Unfavorable perceptions of fellow residents, differing power differentials, a general lack of trust-toward other community members, government and third sector outsiders-and internal power plays also contribute to creating a sub-level conflict environment. An inability to decentralize power, the failure to create an equitable exchange between partners, or to overcome personality issues, can lead to bad partnership linkages that can have negative and destructive consequences for all those involved [103].

\section{Policy Considerations}

Despite the failures of Rio's current policy framework, lessons can still be learned. The State could still offer Rocinha's residents the opportunity to become involved in implementing solutions to the problems they face. Where environmental protection or rehabilitation is the goal, one strategy that might prove useful is the adoption of a comanagement system whereby, for example, government agencies, local individuals, NGOs, and the private sector collectively participate in processes that promote community stewardship of land and ecosystem service protection by providing incentives to residents.

Informal sector environmental governance systems have been proven effective in a variety of contexts internationally (in several instances more effective than government undertakings) [104]. Government can contribute to poverty reduction by introducing sources of income generation in the form of individual stipends, organizational grants, tax or service breaks that incentivize stewardship [105] and provide tangible benefits to recipients. Micro-credit or solidarity financing could also be offered to enterprises that engage in sustainable resource use or direct use forms of ER. Some of these frameworks already exist in one form or another in Brazil [106], and could be adapted to favela needs, however the majority are currently geared toward benefiting State interests, rather than the poor, and most still fail to reach those who need support most [107]. Furthermore, attempting to alleviate poverty through rewarding environmental stewardship efforts is a complex undertaking. For example, attaching overly bureaucratized regularization conditions to financial remuneration packages or subsidies may frustrate individual agency and impede the already stressed decisionmaking apparatus of people and organizations struggling to function in poverty.

One inclusive measure that could be integrated into Rio's urban master plan is the provisioning of spaces for community gardens, urban agriculture, and the protection or expansion of green space in favelas. This would create a scaffolding to grow a semi-autonomous, internally managed favela network where sustainability plays a central role. This long-term view for cultivating multidimensional sustainability [108] is reflective of the kind of integrative policy that Rio so 
often promotes but does little to support. The protection or remediation of public urban space can only become sustainable if the coming together of local stakeholders cooperate to develop and implement mutually beneficial community management strategies. This requires municipal-level, critical infrastructure investment, capital infusion, and access to a range of resources from training in natural and cultural resource management to solidarity financing. Several incentives worldwide provide regional policy support for community ecosystem protection and environmental stewardship through initiatives such scholarships, employment, and financial compensation [109].

By and large, however, Rio's rapid urban intervention policies, rather than alleviating the multiple crises that the city's informal sectors face, have multiplied the vulnerabilities and inequalities that confront the people living in Rocinha and other urban favelas that are subject to the State's interventionist policies. As competition for resources inside favelas becomes increasingly accelerated by government seizures, population increases, climate change, ecosystem services scarcity, an absence of productive public space, and an evergrowing built density-inclusive and multi-dimensional crisis management efforts must be authentically put in place. Yet, while data, visibility, and discourse are building to reveal the extent of these needs, Rio's interventions have failed to take on these problems in any logical or meaningful way. In theory, a socio-environmental strategy such as micro-gardening is a viable concept to realize in Rocinha, but with the chronic lack of social cohesion and stability, and the inadequacies of State intervention, and with vast amounts of state dispensed, federal money disappearing and leaving projects unfinished, this remains far from practically achievable. A number of factors have undermined the ability to deliver any significant social provisioning. These include weak state capacity and lack of transparency among government and corporate entities, failure to prioritize community needs, a lack of vision or support for local environmental restoration efforts, inappropriate government oversight that fails to deliver quality infrastructure, and the general neglect of the needs of the people.

\section{Conclusion}

This paper aims to illuminate on how institutions such as the economy, the legal system, and the State are currently influencing the struggle between the politics of imposed identity and the politics of self-positioning inside Rocinha. If serious policy and judicial reform were undertaken, Rio could initiate inclusive socio-environmental programs to bring improvements to the lives of favela residents. However, transparency is lacking in several dimensions and reform is unlikely. As things stand, access to useful and relevant information remains obscured; citizens and local stakeholder groups are not consulted or taken seriously; there is little effort on the part of the government to learn from or communicate openly or comprehensively with citizens or citizen groups; and there is a lack of vision to prioritize sustained efforts that add value to public space.
Effective governance enables citizen participation, and citizen participation is a key indicator of effective governance. But good governance requires promoting citizens' rights and enabling two-way communication between citizens and government [110]. Yet, as this research demonstrates, delivering inclusivity and social protection to the informal sector has less to do with policy agenda-setting and implementation than with politics and profit.

This paper reveals the aggravated frustrations that involve cultivating productive green space inside Rio's largest and most densely populated urban favela at a time of great upheaval. It exposes how State intervention is framed through the current policy of pacification, and is associated with territorial control and access to land. As well, it describes some of the reasons why community projects, such as the efforts to establish the gardens described, are so difficult to sustain.

In Rio and elsewhere, pressure is building on the growing need to develop socio-environmental policy that addresses resource inequity, especially in areas of poverty [111]. The inclusive co-production of cared for, green public space is integral to the generation of solution-oriented narratives and texts that can encourage critical thinking around interventions in favelas-about how they are defined and how they impact communities. Images and perceptions of poverty are often narrowly focused on economic prosperity, with little value placed on other forms of wealth. Social practices such as building gardens can challenge this perception. Community mobilization and action can stimulate different views, challenge bias, and cultivate a sense of community ownership that can be seen as fragments of what E.P. Thompson conceptualized as a 'moral economy' [112]. The theory of a moral economy encompasses self-affirming behaviors, attitudes and beliefs of excluded peoples in response to social justice issues that relate to their local environment and economy.

The projects such as the ones discussed in this paper also draw attention to the local, citizen-centered social agreements that are being structured to address the socio-environmental needs of Rocinha residents. They are indicative of a diverse range of coalitions that have the potential to foster capacity building and social protection, even though some may fail. These efforts are suggestive of the types of resistance strategies that occur when local subsistence is threatened or abused by State or market forces [113]. They also point to the reality of how State intervention plays out on the ground, whether it be in the form of formalized service delivery, housing regulation policy, or public security actions-that State intervention is focused on building the capacity of the State, not the informal sector, and any meaningful legitimization of public policy in regards to improvements offered to Rocinha residents has yet to be effectively proved.

Further, it connects how the promise of global capital reward, exaggerated by Rio's investment in transforming itself into a mega-event city, has shaped its urban policy landscape to dramatically affect the city's favelas at this 
moment in the $21^{\text {st }}$ century. The speculative lure of return generated by Rio's mega-events not only bites into both the molar dimensions of globalization, but likewise exerts great influence over molecular politics inside favela communities.

It is to be expected that controversy will arise in regard to developing any project in a favela. Working in conflict touches on deeply embedded views and attitudes. It is crucial to have a clear understanding of why and how to take a particular approach within a particular context, and to what ends. It is also essential to consider if there is real benefit to a community, or if there are adequate safety measures in place to be able to work without putting people at risk.

Yet despite the insurmountable challenges, as physical platforms for producing public space, the gardens discussed in this paper do deserve some merit. They provided some food insecurity relief and bolstered nutrition uptake for a handful of beneficiaries. They attracted biodiversity where before there was none. They reduced the presence of trash, improved air quality, and reduced vermin infestations. They were able to catalyze some basic level of network-building and joint collaboration. They brought therapeutic benefits to those involved. And increased community awareness of how desireable public space could be produced, and highlighted the DIY potential of cultivating productive green space. In addition, they provided productive community activity for the unemployed, created knowledge exchange opportunities, promoted intergenerational and cross-cultural interactions, and fostered inclusivity and a culture of collective, communityled management. However, the outcomes were often contradictory, and all in all, implied that any hope of effectively producing citizen-centered green space needs to be given much higher levels of sustained support for it to bring any real benefits to the residents of Rio's urban favelas [114].

To foster a decent quality of life for growing favela populations, and put favelas on a solid and sustainable footing, business subsidies, social investment, and economic incentives must be redirected to reflect resident priorities. This means addressing issues such as land tenure security, solidarity and capacity building, poverty alleviation, stable ecosystem service access, education, sanitation, and so on-rather than focusing on policies that are driven by the politics of development interests and enforced through military occupation and dispossession.

This requires good governance that views multiple dimensions of human security-economic stability, poverty reduction, social development, ecological sustainability, and a living environment free of armed conflict as interconnected

\section{References and Notes}

[1] Within the context of this paper, the word 'community' is used to describe whichever of the $25+$ neighborhoods of Rocinha is under discussion. It is also used to refer to any number of smaller residential or mixed use sub-communities that are located within the immediate vicinity of the project that is being referenced. goals. At a local level, this means forming meaningful operational links between formal and informal institutions. On all levels (government, judicial, corporate and civil) this requires eliminating undue influence and corruption and creating a method for independently investigating various forms of misconduct.

The benefits of engaging in environmental restoration activities in Rocinha are attractive, but these activities are unstable and temporary at best. Until government reform is undertaken, and inclusivity prioritized, abandonment, oppression, insecurity and fear will largely determine the way people perceive of institutional intervention. In all likelihood, this will continue to obstruct favela residents from having any high expectations of rights, or looking to the State to alleviate their problems.

Undertaking the difficult task of building a better future for the city's poorer residents is especially complex and difficult in large favelas like Rocinha. Land tenure security, drug trafficking, police brutality, and other issues related to territorialism are all stressors. Therefore it is imperative that the social and moral insolvencies of Rio's current policy approach be confronted. Comprehensive changes that refocus on providing decent socio-economic opportunities for residents and improving their general living conditions are interconnected goals that can be brought closer together by efforts that support citizen-centered sustainability initiatives, build green infrastructure, and cultivate safe social space [115].

The opportunity for favelas to become a model for integrating the ecological, socio-economic, planning and political realms may be incapacitated by the State however insights that point to the linkages between ecology and urban design can still be gleaned. Environmental restoration as an urban design experiment is a platform whereby political, ecological and social outcomes can be analyzed to determine how the power relations between favela communities and State institutions can draw the strands of ecology, planning, and informality together, or push them apart. Acknowledging the role that spatial and social heterogeneity play in both ecological and social functioning of urban favelas is essential to understanding the potential integrating power of community-led ER activities, the socio-ecological patch dynamics of these communities, the value and conflict generated by spatial sub-community mosaics, and the recognition that favelas comprise of a myriad of adaptable socio-political systems in which people respond to, and can affect ecological change.

[2] Valladres L. A Invenção da favela. 1st ed. Rio de Janeiro, RJ, Brazil: FGV; 2005.

[3] RJ State Law 5890/11: Criteria to establish the implementation of Policing Pacifying Units - UPPS-in the Scope of the State of Rio de Janeiro; 2011. Available from: http://gov-rj.jusbrasil.com.br/legislacao/ 1026543/lei-5890-11.

[4] State with an uppercase ' $S$ ' in this context refers to 
multiple tiers (federal, state and municipal) government agencies acting in official capacity on behalf of institutional goals and interests. It can also be linked to its Marxist roots as articulated by Louis Althusser and co-authors in Reading Capital (see in particular the original French edition 1965); and by Antonio Gramsci, whose work in political theory and sociology studies deconstructs how states use cultural institutions to maintain power in capitalist societies.

[5] See James Freeman, Janice Perlman, Robson Rodrigues, Robert Muggah, Mark Neocleous, Loïc Wacquant, Joseph da Silva, Marcelo Burgos, Mario Brum, Luiz Fernando Almeida, Ester Werling, Luanda Vannuchi, Mathieu Van Criekingen, Carlos Vainer, Einar Braathen, Eric Swyngedouw, Ignacio Cano, Theresa Williamson, Mauro Amboroso, Karin Schwambach, and Mariana Cavalcante.

[6] Gomes MFCM, Barbosa MJDES. Cidade e Sustentabilidade: Mecanismos de controle e resistência. Rio de Janeiro, RJ, Brazil: Terra Vermelha; 2010.

[7] Cavalcante LR. Sustentabilidade Urbana: Do discurso oficial à implementação nas Favelas de Praia da Rosa e Sapucaia. In: V Jornada Internaticional de Políticas Publicas. São Luís, MA, Brazil: Federal University of Maranhão; 23-26 August 2011. Available from: http://www.joinpp.ufma.br/jornadas/ joinpp2011/CdVjornada/JORNADA_EIXO_2011/ QUESTAO_URBANA_E_GESTAO_DAS_CIDADES/ SUSTENTABILIDADE_URBANA.pdf.

[8] RJ State Complementar Law 111/2011; 2011. Available from: http://mail.camara.rj.gov.br/APL/Legislativos/ contlei.nsf/a99e317a9cfec383032568620071f5d2/ cdd6a33fa14df524832578300076df48? OpenDocument.

[9] Borges D. O medo do crime na ciddae do Rio de Janeiro: Uma análise sob a perspectiva das crenças de perigo. Curitiba, PR, Brazil: Appris; 2012.

[10] De Souza e Silva J. As Unidades Policiais Pacificadoras e os novos desafios para as favelas cariocas. In: Aspectos Humanos da Favela Carioca: Ontem e Hoje. Rio de Janeiro, RJ, Brazil: Laboratório de Etnografia Metropolitana/IFCS - UFRJ; 2010. Available from: http://observatoriodefavelas.org.br/wpcontent/uploads/2013/06/Aspectos-humanos-dasfavelas-cariocas.pdf.

[11] Bourdieu P. A economia das trocas simbólicas. 6th ed. São Paulo, SP, Brazil: Perspectiva; 2005.

[12] Leite MP. Entre o individualismo e a solidariedade: Dilemas da política e da cidadania no Rio de Janeiro. Revista Brasileira de Ciências Sociais. 2000;15(44):43-90.

[13] Engdahl E, Muller T. The European contribution to symbolic interactionism. Symbolic Interaction. 2015;38(3):431-441.

[14] Muller T. Contributions from European Symbolic Interactionists: Conflict and cooperation. Studies in ed. Muller T, editor. Bingley: Emerald; 2015.
[15] Carr W, Kemmis S. Becoming Critical. Education, knowledge and action research. New York, NY, USA: Routledge; 1986.

[16] Turnbull M, Turvill E. Participatory Capacity and Vulnerability Analysis: A practitioner's guide. Oxford, UK; 2012. Available from: http://policy-practice.oxfam. org.uk/publications/participatory-capacity-andvulnerability-analysis-a-practitioners-guide-232411.

[17] Bogdan R, Biklen SK. Qualitative Research for Education: An Introduction to Theories and Methods. 5th ed. Boston, MA, USA: Allyn and Bacon; 1992.

[18] Statistics are primarily derived from Institute Public Security (ISP), Instituto Pereira Passos (IPP), Laboratório de Análise da Violência (LAV), and the Instituto Brasileiro de Geografia e Estatística (IBGE).

[19] During the course of conducting this research, GMF work also interfaced with the Secretaria Municipal de Meio Ambiente (SMAC), Secretaria Municipal de Habitação (SMH), Secretaria de Estado de Assistência Social e Direitos Humanos (SEASDH), Programa de Aceleração do Crescimento (PAC), Empresa de Obras Públicas do Estado do Rio de Janeiro (Emop), Amigos dos Amigos (ADA), and the the Unidade de Polícia Pacificadora (UPP).

[20] Rekow L. Pacification \& Mega-events in Rio de Janeiro: Urbanization, Public Security \& Accumulation by Dispossession. Journal of Human Security. 2016;12(1):4-34.

[21] Amnesty International. Brazil: You killed my son: Homicides by military police in the city of Rio de Janeiro. Rio de Janeiro, RJ, Brazil: Amnesty International Brazil; 2015. Available from: https://www. amnesty.org/en/documents/amr19/2068/2015/en/.

[22] Schwambach KF. Mega-Events in Rio de Janeiro and their Influence on the City Planning. In: 15th International Planning History Society Conference. São Paulo, SP, Brazil; 17 July 2011. Available from: http: //www.fau.usp.br/iphs/abstractsAndPapersFiles/ Sessions/20/SCHWAMBACH-KARIN.PDF.

[23] Municipal Government of Rio de Janeiro. Cidade Olímpica - Morar Carioca. Available from: http: //www.cidadeolimpica.com.br/morar-carioca/.

[24] Prefeitura do Rio de Janeiro. Legal Decree 36388.29.10.2012 (Morar Carioca); 2012. Available from: $\quad$ http://www.iabrj.org.br/morarcarioca/wpcontent/uploads/2012/11/decreto_36388.29.10. 2012_morar_carioca.pdf.

[25] Plano Director de Desenvolvimento Urbano Sustentável Sistema Integrado de Planejamento e Gestão Urbana. Rio de Janeiro, RJ, Brazil: Prefeitura do Rio de Janeiro Secretaria Municipal de Urbanismo; 2011. Available from: http: //www.rio.rj.gov.br/dlstatic/10112/5333332/4151408/ 43CoordCTPDArticulacaoPDPE112015.pdf.

[26] Steiker-Ginzberg K. Morar Carioca: The Dismantling of a Dream Favela Upgrading Program. Rio On Watch. 2014 September 10; Available from: http: 
//www.rioonwatch.org/?p=17687

[27] Häussermann H, Siebel W, Birklhuber D. Festivalisierung der Stadtpolitik: Stadtentwicklung durch grosse Projekte. Opladen, Germany: Westdeutsche Verlag; 1993.

[28] Freeman J. Neoliberal accumulation strategies and the visible hand of police pacification in Rio de Janeiro. Revista de Estudos Universitários. 2012;38:95-126.

[29] Censo 2010. Instituto Brasileiro de Geograpfia e Estatística (IGBE); 2010. Available from: http: //censo2010.ibge.gov.br/.

[30] Poverty and the City. Rio de Janeiro, RJ, Brazil: International Poverty Center, United Nationsl Development Programme; 2005. Available from: http://cdn.pan.org.za/cdn/farfuture/BAF2OKbe S9t6Q3nY9TpQNMsa_w1 mptJQZkmaMRTpMs/ mtime:1425295200/sites/default/files/ publicationdocuments/IPCPovertyInFocus.pdf.

[31] Rodrigues R. The Dilemmas of Pacification: News of War and Peace in the 'Marvelous City'. Stability: International Journal of Security \& Development. 2014;3(1):22.

[32] Lopes de Souza M. The socio-political fragmentation of space and 'micro-level warlords' as challenges for emancipative urban struggles. City. 2009;13(1)26-52.

[33] Phillips T. Brazilian 'drug lord' sees reign as 'king of the hill' end in car boot. The Guardian. 2011 November 11; Available from: http://www.theguardian.com/ world/2011/nov/11/brazilian-drug-lord-car-boot.

[34] Rekow L. Police, Protests, and Policy in Rio de Janeiro-Mega-Events, Networked Culture, and the Right to the City. In: Foth M, Brynskov M, Timo O, editors. Citizen's Right to the Digital City: Urban Interfaces, Activism, and Placemaking. 1st ed. Singapore: Springer; 2016. pp. 119-136.

[35] Secretaria Nacional de Habitação. Urbanização de Favelas: a experiência do PAC. Brasília, BR, Brazil: Ministério das Cidades; 2010. Available from: http://www.capacidades.gov.br/biblioteca/detalhar/ id/166/titulo/urbanizacao-de-favelas-\#prettyPhoto.

[36] Azevedo L, Faulhaber L. SMH 2016: Remoções no RJ Olímpico. Mórula; 2015. Available from: http://www.morula.com.br/catalogo/smh2016/.

[37] "Elite brasileira é muito demofóbica e adora falar"; veja frases de Paes. UOL Notícias. 2015 July 22. Available from: http://noticias.uol.com.br/politica/ ultimas-noticias/2015/07/22/elite-brasileira-e-muitodemofobica-e-adora-falar-veja-frases-de-paes.htm.

[38] TCM determina demolição de 12 casas na Rocinha. Rio de Janeiro, RJ, Brazil: Legislative Assembly of the State of Rio de Janeiro; 2006. Available from: http://www.alerj.rj.gov.br/common/noticia_corpo. asp?num $=4420$.

[39] Explaining Rio de Janeiro Habitation Policy. Rio de Janeiro, RJ, Brazil: Municipal Government of Rio de Janeiro; 2015. Available from: https://medium.com/explicando-a-politica-dehabitacao-da-prefeitura/download-explaining-riode-janeiro-habitacional-policy-9278c331f2e1.

[40] Ivins C, Maciel IMS. Geopolíticas de território e territorialidade: Dilemas na construção de "identidades comunitárias" na Roupa Suja, Rocinha. Rio de Janeiro: Instituto de Pesquisa Econômica Aplicada; 2011. Available from: http://www.ipea.gov.br/code2011/ chamada2011/pdf/area5/area5-artigo6.pdf.

[41] Schmidt S. Associação contabiliza 210 construções irregulares em área de proteção na Rocinha. O Globo. 2015 May 17; Available from: http://oglobo.globo.com/ rio/associacao-contabiliza-210-construcoes-irregularesem-area-de-protecao-na-rocinha- 16183585.

[42] Lauriano C. Sem traficante Nem, área de risco da Rocinha terá mais remoções. O Globo G1 Rio. 2011 November 16; Available from: http: //g1.globo.com/rio-de-janeiro/noticia/2011/11/semtraficante-nem-area-de-risco-da-rocinha-tera-maisremocoes.html.

[43] Megaeventos e Violações dos Direitos Humanos no Rio de Janeiro. Rio de Janeiro, RJ, Brazil: Comitê Popular da Copa e Olimpíadas do Rio de Janeiro; 2014. Available from: https://comitepopulario.files.wordpress.com/2014/ 06/dossiecomiterio2014_web.pdf.

[44] Favelas avançam sobre 0 verde no Rio. O Globo. 2010 June 16; Available from: http://oglobo.globo.com/rio/favelas-avancamsobre-verde-no-rio-2987225.

[45] Willis A. PAC Programs Stalls in Rocinha, Despite Record Spending. The Rio Times. 2012 November 20; Available from: http://riotimesonline.com/brazil-news/riopolitics/pac-programs-stall-in-rocinha-favela.

[46] Magalhães LE. Ocupações de encostas já custaram $\mathrm{R} \$ 2,5$ bi aos cofres públicos em 16 anos; 2010. Available from: http://oglobo.globo.com/rio/ocupacoes-deencostas-ja-custaram-25-bi-aos-cofres-publicosem-16-anos-2974918.

[47] Tuberculose na Rocinha: "A Rocinha não precisa de teleférico, mas sim de saneamento básico". El País. 2015 September 12; Available from: http://brasil.elpais.com/brasil/2015/09/03/ politica/1441270863_849228.html.

[48] Luiz G. Quase metade da população não tem acesso à rede de esgoto, diz governo. O Globo G1 Rio. 2016 February 16; Available from: http://g1.globo.com/distritofederal/noticia/2016/02/quase-metade-da-populacaonao-tem-acesso-rede-de-esgoto-diz-cidades.html.

[49] Adams W, Hutton J. People, Parks and Poverty: Political Ecology and Biodiversity Conservation. Conservation and Society. 2007;5(2):147-183. Available from: http://www.conservationandsociety.org/article. asp?issn=0972-4923; year=2007; volume $=5$;issue = 2 ; spage $=147$; epage $=183$; aulast $=$ Adams .

[50] Lovell R, Husk K, Bethel A, Garside R. What are the health and well-being impacts of community garden- 
ing for adults and children: a mixed method systematic review protocol. 2014;3(20).

[51] Orsini F, Kahane R, Nono-Womdim R, Gianquinto G. Urban agriculture in the developing world: A review. Agronomy for Sustainable Development. 2013;33(4):695-720.

[52] Stewart R, Korth M, Langer L, Rafferty S, Da Silva $\mathrm{N}$, van Rooyen $\mathrm{C}$. What are the impacts of urban agriculture programs on food security in low and middle-income countries? Environmental Evidence. 2013;2(1):7.

[53] Arruda J. Agricultura Urbana na Região Metropolitana do Rio de Janeiro: Sustentabilidade e Repercussões na Reprodução das Famílias [PhD Thesis]. Federal University of Rio de Janeiro, RJ, Brazil; 2011. Available from: http://r1.ufrrj.br/cpda/wp-content/ uploads/2012/07/Tese_Juliana_Arruda_20111.pdf.

[54] O'Reilly EdM. Agricultura Urbana-Um Estudo de Caso do Projeto Hortas Cariocas em Manguinhos, Rio de Janeiro [PhD Thesis]. Federal University of Rio de Janeiro, RJ, Brazil; 2014. Available from: http://monografias.poli.ufrj.br/monografias/ monopoli10009377.pdf.

[55] Halder SJB, de Mendonça MM, Monteiro D. Agricultura urbana: Natural aqui do Rio de Janeiro. AS-PTA. 2008; Available from: http://aspta.org.br/wpcontent/uploads/2011/05/Agricultura-Urbananatural-aqui-do-Rio-de-Janeiro.pdf.

[56] Rekow L. Urban agriculture in the Manguinhos favela of Rio de Janeiro: Laying the groundwork for a greener future. In: Filho WL, Pociovalisteanu D, Quasem Al-Amin A, editors. Sustainable Economic Development: Green Economy and Green Growth. world sust ed. Singapore: Springer; 2016. .

[57] Rekow L. Green My Favela-An act of defiance. International Journal of Education through Art. 2012;8(3):305-319.

[58] Herrera A, Guglielma da Passano M. FAO Land Tenure Manuals 2: Land tenure alternative conflict management. Rome, Italy: Food and Agriculture Organization of The United Nations; 2006. Available from: ftp://ftp.fao.org/docrep/fao/009/a0557e/ a0557e00.pdf.

[59] Taru J, Basure HS. Conflicts, Contestation and Marginalization in Urban Agriculture: Experiences from Kuwadzana Extension, Harare. Russian Journal of Agricultural and Socio-Economic Sciences. 2013;6(18). Available from: http://www.rjoas.com/ issue-2013-06/article_03.pdf.

[60] Urban Agriculture For Sustainable Poverty Alleviation and Food Security. Rome, Italy: Food and Agriculture Organization of The United Nations; 2008. Available from: http://www.fao.org/fileadmin/templates/FCIT/ PDF/UPA_-WBpaper-Final_October_2008.pdf.

[61] Mani A, Mullainathan S, Shafir E, Zhao J. Poverty impedes cognitive function. Science. 2013;34(6149):976-80.
[62] Spears D. Economic decision-making in poverty depletes cognitive control. BE Journal of Economic Analysis \& Policy. 2011;11(1).

[63] Weber EU, Baron J, Loomes G. Conflict and Tradeoffs in Decision Making. Cambridge, UK: Cambridge University Press; 2001.

[64] World Health Organization, Blas E, Sivasankara Kurup A. Equity social determinants and pubic health programmes. World Health Organization; 2010. Available from: http://apps.who.int/iris/bitstream/10665/ 44289/1/9789241563970_eng.pdf.

[65] McPhearson T. Vacant Land in Cities Could Provide Important Social and Ecological Benefits. The Nature of Cities. 2012 August 21; Available from: http://www.thenatureofcities.com/2012/08/ 21/vacant-land-in-cities-could-provide-importantsocial-and-ecological-benefits/.

[66] Violence in the City: Understanding and Supporting Community Responses to Urban Violence. The World Bank Social Development Department, Conflict, Crime and Violence Team; 2011. Available from: http://www.unicef.org/protection/Violence_in_ the_City.pdf.

[67] Jiang S. Therapeutic landscapes and healing gardens: A review of Chinese literature in relation to the studies in western countries. Frontiers of Architectural Research. 2014;3(2):141-153.

[68] Helphand K. Defiant Gardens: Making Gardens in Wartime. San Antonio, TX, USA: Trinity University Press; 2006.

[69] Parnell J. Sustainability in the favelas: Swapping guns for gardens-Climate Home. Climate Change News. 2012 June 13; Available from: http://www. climatechangenews.com/2012/06/13/sustainabilityin-the-favelas-swapping-guns-for-gardens/.

[70] Rinaldi A. New ISP Report Shows Crime on the Rise in Rio de Janeiro. The Rio Times. 2014 January 21; Available from: http://riotimesonline.com/brazilnews/rio-politics/new-report-shows-crime-on-therise-in-rio/.

[71] Molinari M, Rossi M. Rio+20 Events in Favela Communities. The Rio Times. 2012 June 19; Available from: http://riotimesonline.com/brazil-news/riopolitics/rio20-events-in-favela-communities/.

[72] Rekow L. Fighting insecurity: Experiments in urban agriculture in the favelas of Rio de Janeiro. Field Actions Science Reports. 2015;8. Available from: http://factsreports.revues.org/4009.

[73] Jehn K, Bendersky C. Intragroup Conflict in Organizations: A Contingency Perspective on the ConflictOutcome Relationship. Research in Organizational Behavior. 2003;25:187-242.

[74] Roseman IJ, Wiest C, Swartz TS. Phenomenology, behaviors, and goals differentiate discrete emotions. Journal of Personality and Social Psychology. 1994;67(2):206-221.

[75] Swann WB, Polzer JT, Seyle C, Ko S. Finding 
Value in Diversity: Verification of Personal and Social Self-views in Diverse Groups. Academy of Management Review. 2004;29:9-27. Available from: http://homepage.psy.utexas.edu/homepage/ faculty/swann/docu/swann_polzer_seyle_ko.pdf.

[76] Carnevale PJ, Probst TM. Social values and social conflict in creative problem solving and categorization. Journal of Personality and Social Psychology. 1998;74(5):1300-1309.

[77] Rispens S. Beneficial and detrimental effects of conflict. In: Ayoko O, Ashkanasy N, Jehn K, editors. Handbook of Conflict Management Research. Cheltenham, UK: Edward Elgar; 2014. pp. 19-32.

[78] Health Inequalities in Rio de Janeiro, Brazil: Lower Healthy Life Expectancy in Socioeconomically Disadvantaged Areas. American Journal of Public Health. 2011;101(3):517-523.

[79] O Globo. Dengue: mais de 2 mil imóveis são vistoriados na Rocinha. Jornal $O$ Globo. 2011 November 28; Available from: http://oglobo.globo.com/rio/dengue-mais-de-2mil-imoveis-sao-vistoriados-na-rocinha-3271080.

[80] Rocinha ainda lidera o ranking da tuberculose no estado. Rocinhaorg. 2016; Available from: http: //rocinha.org/noticias/rocinha/view.asp?id=1378.

[81] Perlman J. Favela Four Decades of Living on the Edge in Rio De Janeiro. Oxford, UK; 2010.

[82] Soares R. Moradores da Rocinha denunciam que traficantes estabeleceram toque de recolher. 2013 November 8; Available from: http: //extra.globo.com/casos-de-policia/moradores-darocinha-denunciam-que-traficantes-estabeleceramtoque-de-recolher-10720387.html.

[83] Melo S. "Operação Paz Armada" desarticula tráfico na Rocinha; 2013. Available from: http://www. policiacivil.rj.gov.br/exibir.asp?id=17246.

[84] Jacobs J. The Death and Life of Great American Cities. New York, NY, USA: Random House; 1961.

[85] Valdevino D. Porta-voz de UPPs assume que parte da Rocinha foi retomada por traficantes. O Dia. 2015 March 31; Available from: http://odia.ig.com.br/noticia/rio-de-janeiro/201503-31/coordenador-de-upp-assume-que-parte-darocinha-foi-retomada-por-traficantes.html.

[86] Traficantes impõem terror na Rocinha e atacam UPP. Brasil 247. 2014 February 17; Available from: http://www.brasil247.com/pt/247/favela247/130476/ Traficantes-imp\%C3\%B5em-terror-na-Rocinha-eatacam-UPP.htm.

[87] Polícia prende, na Rocinha, acusado de estuprar americana. O Globo Extra. 2014 July 3; Available from: http://extra.globo.com/casos-depolicia/policia-prende-na-rocinha-acusado-deestuprar-americana-13123226.html.

[88] Ribeiro A, Soares R. Menina é encontrada morta em terreno a cerca de 100 metros da UPP da Rocinha. O Globo Extra. 2013 September 9; Available from: http://extra.globo.com/casos-de-policia/meninaencontrada-morta-em-terreno-cerca-de-100metros-da-upp-da-rocinha-10193310.html.

[89] Darlington S. Eco-wall or segregation: Rio plan stirs debate. CNN. 2009 December 9; Available from: http://edition.cnn.com/2009/WORLD/americas/ 12/09/brazil.ecowall/.

[90] Facilities included an ampitheater, a playground, and a number of sports and recreation facilities. Recycled and repurposed materials (acquired from the homes demolished in the region) provided many of the construction materials.

[91] Frayssinet F. Nature Paths Instead of Wall for Rio Slum. Inter Press Service. 2009 June 8; Available from: http://www.ipsnews.net/2009/06/nature-pathsinstead-of-wall-for-rio-slum/.

[92] Rolnick is an architect, urban planner, and was special rapporteur to the UN Human Rights Council on the Right to Adequate Housing from 2008-2014.

[93] Rolnik R. Jardim Botânico, Rio de Janeiro: mais um capítulo-infeliz-de uma questão não resolvida. Blog of Raquel Rolnik.

[94] Cavalcante V. Parque Ecológico da Rocinha será inaugurado em dezembro. Governo do Rio de Janeiro website. 2012 July 13; Available from: http://www.rj.gov.br/web/imprensa/exibeconteudo? article-id=1008722.

[95] Rocinha vai ganhar $1^{\circ}$ parque em favela do Rio. O Globo G1 Rio. 2012 July 22; Available from: http://g1.globo.com/brasil/noticia/2012/07/rocinhavai-ganhar-10-parque-em-favela-do-rio.html.

[96] Rossi E. Rio, favela eco-sostenibile grazie a riciclo e orti urbani. Sky TG24. 2012 November 15; Available from: http://tg24.sky.it/tg24/eco_style/2012/11/15/ riciclo_orti_urbani_green_my_favela_rocinha_rio_de_ janeiro_brasile_eco_sostenibile_.html.

[97] Though many property owners build on lajes without licenses, injunctions and the overwhelming bureacracy that chokes the municipal departments of Urban Planning and the Environment prevents actions from being taken against these properties.

[98] Tuberculose na Rocinha expõe o Brasil que estacionou no século XIX. Website Instituto Humanitas Unisinos. 2015 September 15; Available from: http://www.ihu.unisinos.br/noticias/546729tuberculose-na-rocinha-expoe-o-brasil-queestacionou-no-seculo-xix.

[99] Rodrigues L. Rocinha: "Falam de aproximação com o morador, mas a entrada da UPP é um terror". Jounal do Brasil. 2016 April 21; Available from: http://www.jb.com.br/rio/noticias/2014/08/17/ rocinha-falam-de-aproximacao-com-o-moradormas-a-entrada-da-upp-e-um-terror/.

[100] Osborn C. A Check on Trust for Rio's Expanding Pacification Program. Americas Quarterly. 2013 October 11; Available from: http://www.americasquarterly.org/content/check- 
trust-rio-expanding-pacification-program.

[101] Rocinha residents fought against eviction and won, now the city is investing in their community. Mundo Real. 2013 September 26; Available from: http://mundoreal.org/from-eviction-to-investmenthow-the-community-of-laboriaux-fought-againsteviction-and-won.

[102] This is not to suggest that people with mental health issues have more propensity to violence than others in the general population. Statistics show that people with mental health issues are more likely to be victims of violence rather than perpetrators of it (Canadian Mental Health Association, 2011).

[103] GMF's working guidelines are closely aligned with the partnership principles of Oxfam. They include, for example, holding initial meetings with potential partners and participants one at a time or in small groups, showing respect for the views of others, challenging ideas (not people), using understandable language and concepts, allowing everyone to express their views, ensuring everyone is heard and listened to, and giving clear reasons for, and benefits of, a particular project.

[104] Guha-Khasnobis B. Oxford, UK: Oxford University Press; 2009.

[105] This was reflected in Recommendation 5.16 (on good governance) and 5.25 (on co-management) of the $\mathrm{V}^{\text {th }}$ International Union for Conservation of Nature's World Parks Congress, Durban, South Africa, 2003.

[106] Existing examples that could be adapted for this, include Hortas Cariocas (urban agriculture employment stipends), the ICMS Ecologico (tax breaks for conservation efforts), Bancos do Povos (micro-credit loans).

[107] Cravalho de Franca Filho $G$ et alii. Policies of Microcredit in Brazil : an analysis from the case of Community Development Banks (CDBs). Journal du Mauss. 2012 March 3. Available from: http://www.journaldumauss.net/?Policies-of-
Microcredit-in-Brazil.

[108] Redford KH, Coppolillo P, Sanderson EW, Da Fonseca GAB, Dinerstein E, Groves C, et al. Mapping the Conservation Landscape. Conservation Biology. 2003;17(1):116-131.

[109] McShane TO, Wells MP. Getting Biodiversity Projects to Work: Towards More Effective Conservation and Development. New York, NY, USA: Columbia University Press; 2004.

[110] The Contribution of Government Communication Capacity to Achieving Good Governance Outcomes. Washington, DC, USA: George Washington University Institute for Public Diplomacy \& Global Communication and CommGAP; 2009. Available from: http://siteresources. worldbank.org/EXTGOVACC/Resources/ GWCommGAProundtablerapporteursreport.pdf.

[111] Perch L. Understanding the Socio-Environmental Policy Space: International Policy Center for Inclusive Growth. Brasilia, DF, Brazil: International Policy Center for Inclusive Growth, United Nations Development Programme and he Government of Brazil; 2012. Research Brief $n^{\circ} 20$. Available from: http://www.ipcundp.org/pub/IPCPolicyResearchBrief20.pdf.

[112] Thompson EP. The Making of the English Working Class. New York, NY, USA: Random House; 1963.

[113] Root HL. The Fountain of Privilege, Political Foundations of Markets in Old Regime France and England. Los Angeles, CA, USA: University of California Press; 1994.

[114] Stern M, Seifert S. From Creative Economy to Creative Society: A neighborhood-based strategy to increase urban vitality and promote social inclusion. GIA Reader. 2008;19(3). Available from: http://www.giarts.org/article/ culture-and-community-revitalization-collaboration.

[115] Pickett S, Cadenasso ML, Grove JM. Resilient cities: Meaning, models, and metaphor for integrating the ecological, socio-economic, and planning realms. Landscape and Urban Planning. 2004;69:369-384. 